\title{
LEZUZA EN EL CONTEXTO DE LAS GUERRAS CARLISTAS. LA FACCIÓN DEL CURA DE ALCABÓN FUE MASACRADA EN 1874
}

\section{LEZUZA IN THE CONTEXT OF CARLIST WARS. THE PRIEST PAR- TY OF ALCABÓN WAS MASSACRED IN 1874}

\author{
J. Ángel Munera Martínez \\ CEIP Federico Mayor Zaragoza \\ Albacete, JCCM, España \\ angelmunera@gmail.com
}

Cómo citar este artículo: Munera Martínez, J. A. (2020). Lezuza en el contexto de las guerras carlistas. La facción del cura de Alcabón fue masacrada en 1874. Al-Basit (65), 113-170. http://doi.org/10.37927/al-basit.65_4

Recibido/Received: 13-05-2020

Aceptado/Accepted: 20-07-2020

RESUMEN: El 27 de diciembre de 1874 se produjo en Pradorredondo, aldea del municipio de Lezuza, un enfrentamiento entre las tropas liberales, dirigidas por el teniente coronel Portillo, y la partida del cura de Alcabón, en el que fueron masacrados 120 carlistas. Este suceso originará lo que hemos llamado "La leyenda de la Bola”. El que dirigía la facción, don Lucio Dueñas, el cura de Alcabón, fue uno de los curas guerrilleros más célebres de la tercera guerra carlista. A través de la prensa histórica hemos reconstruido su biografía. El artículo se complementa con otros hechos acaecidos, en Lezuza y su comarca, durante la primera guerra carlista.

PALABRAS CLAVE: Lucio Dueñas, cura de Alcabón, Portillo, Lezuza, Pradorredondo, guerras carlistas.
ABSTRACT: On the 27th of December in 1874 a confrontation happened in Pradorrendondo, a small village of the town of Lezu$\mathrm{za}$, between the liberal troops, led by the Lieutenant Colonel Portillo, and the Priest Party of Alcabón, in which 120 Carlists were slaughtered. This incident will cause what has been called "The Legend of the Ball". The leader of the party, don Lucio Dueñas, priest of Alcabón, was one of the most famous guerrilla priests of the Third Carlist War, and his biography has been reconstructed through the historical press. The research article is complemented with other events occurred in Lezuza and its region during the First Carlist War.

KEYWORDS: Lucio Dueñas, priest of Alcabón, Portillo, Lezuza, Pradorrendondo, Carlist Wars. 


\section{INTRODUCCIÓN}

El hallazgo de ocho manuscritos en el Juzgado de Paz de Lezuza, fechados en 1874, nos da pie para investigar un hecho de suma importancia para la historia local, que aún hoy se conserva en la memoria popular, transformado en lo que después conoceremos como "la leyenda de la Bola".

Los documentos hacen referencia a un enfrentamiento armado entre las tropas fieles al gobierno de España, dirigidas por el teniente coronel Portillo, contra una facción de carlistas, acaudillada por don Lucio Dueñas, el cura de Alcabón. El combate se saldaría con la matanza de 120 carlistas. La magnitud de la masacre superó, sin lugar a dudas, a cualquier otro enfrentamiento militar que se produjera durante la tercera guerra carlista en la provincia de Albacete.

Los historiadores provinciales y regionales que han tratado el tema de las guerras carlistas, tanto los más próximos a los hechos acontecidos, como Roa Erostarbe (1891-1894) y Sánchez Torres $(1916)^{1}$, como otros posteriores, no hacen referencia a esta matanza; les pasa totalmente desapercibida. Tampoco tuvo información de ella Antonio Pirala (1892), político e historiador, conocido por sus amplias publicaciones sobre las guerras carlistas, a pesar de que en una de ellas dedica un capítulo al cura de Alcabón. No obstante, no transcurre inadvertida para la prensa escrita de la época, al menos a la de Madrid ${ }^{2}$. En la capital de España, sí tuvieron conocimiento de lo que aconteció en Pradorredondo (Lezuza), el día 27 de diciembre de 1874.

Además, el cabecilla que lideraba la partida carlista, don Lucio Dueñas, el cura de Alcabón, fue un personaje famoso en los círculos del carlismo, y llegó a alcanzar una gran popularidad a nivel nacional. Son bastante recurrentes las noticias que encontramos sobre él en los periódicos y revistas de la época. Hasta el propio Benito Pérez Galdós, en un capítulo de los Episodios Nacionales, lo toma como referente para criticar la postura del clero rural en aquella guerra civil, cuando dice:

\footnotetext{
${ }^{1}$ Aunque el año de publicación del libro de Sánchez Torres es 1916, la obra fue presentada en el año 1902 al concurso de unos Juegos Florales organizados por el Colegio de Abogados de la capital de Albacete.

${ }^{2}$ En Albacete, en la fecha en la que ocurren estos hechos, 1874, se publicaba el Boletín Oficial de la Provincia, pero no se conservan en el Archivo Histórico Provincial los números publicados cuando ocurren estos sucesos de Pradorredondo.
} 
"indudablemente, el ejemplar más castizo y pintoresco de aquellos brotes insurreccionales fue el que la Historia designa con el epígrafe de El Cura de Alcabón" (2005, p. 5454).

Por otro lado, el descubrimiento de diversa documentación en los libros parroquiales de Lezuza sobre el fusilamiento de siete personas pertenecientes "al cuerpo de movilizados" en 1838 y de otros cuatro "carabineros" en 1840, a manos de facciones carlistas, unido a varias actas del archivo histórico municipal, conseguimos aportar datos sustanciales para entender cómo vivió la comarca de Lezuza la Primera Guerra Carlista.

Para la historia local, provincial y regional, es importante que se conozcan estos hechos y los personajes que los protagonizaron. Sin duda, este artículo contribuirá a completar los conocimientos que tenemos sobre las guerras carlistas en la provincia de Albacete.

\section{EL CARLISMO}

No es posible comprender la historia contemporánea de España sin prestar una especial atención al carlismo. El carlismo es un movimiento sociopolítico de carácter antiliberal y antirrevolucionario surgido en las postrimerías del Antiguo Régimen, que va a pervivir hasta la Guerra Civil Española (1936-1939), donde sus partidarios se unirán al bando insurrecto (Canal i Morell, 2005, p. 46). El carlismo en España representó la defensa del absolutismo, de la antigua sociedad estamental, del orden social inspirado en una concepción teocrática, de la supremacía ideológica de la Iglesia, del recelo a la cultura urbana y la resistencia del campesinado a cambiar sus formas tradicionales de vida (Aróstegui, 2003, p.17).

Los rasgos esenciales del carlismo, ideológica y socialmente, estaban ya presentes antes de que tuvieran ese nombre. Los podemos encontrar en algunos movimientos que lo precedieron, como el de los "serviles", "realistas", "absolutistas" o "apostólicos", antes de que la figura de don Carlos María Isidro de Borbón se conviritiera en el centro, y hasta en el pretexto, para un dilatado y profundo conflicto político y social entre los partidarios del Antiguo Régimen contra el liberalismo (Asensio, 2011, p. 33).

Los partidarios de don Carlos preveían el acceso al poder cuando este sucediera a su hermano, el rey Fernando VII, ya que no tenía hijos. 


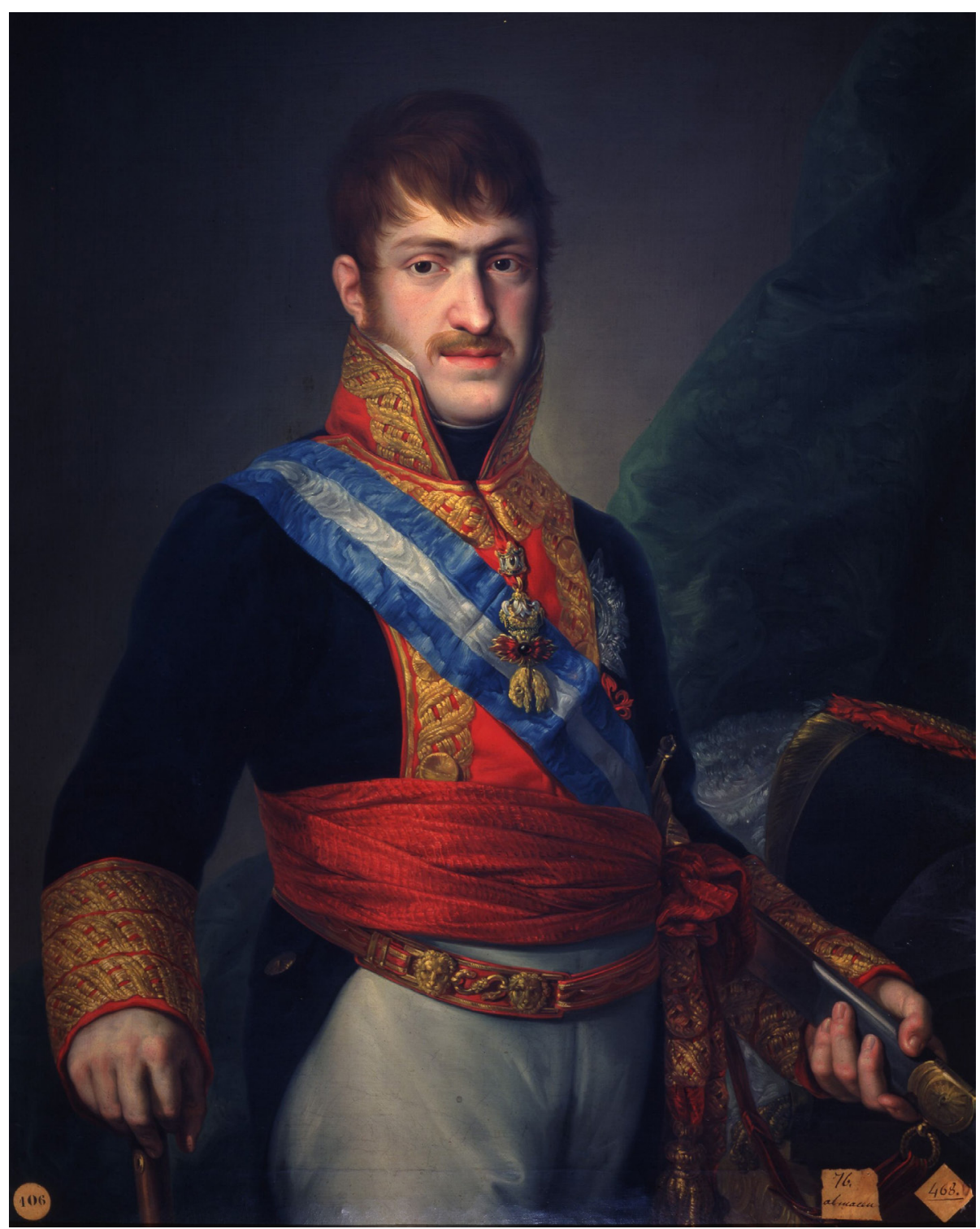

Carlos María Isidro de Borbón (pretendiente carlista al trono, con el título de Carlos V). Autor: Vicente López Portaña, año 1814. Real Academia de Bellas Artes de San Fernando.

- Pero esta situación cambió en 1829, cuando el rey enviudó de su tercera esposa y se casó por cuarta vez con María Cristina de Borbón -Nápoles. : La reina pronto quedó embarazada y la suposición de una descendencia $\approx$ directa del rey alteraba los planes de sucesión a la corona. 


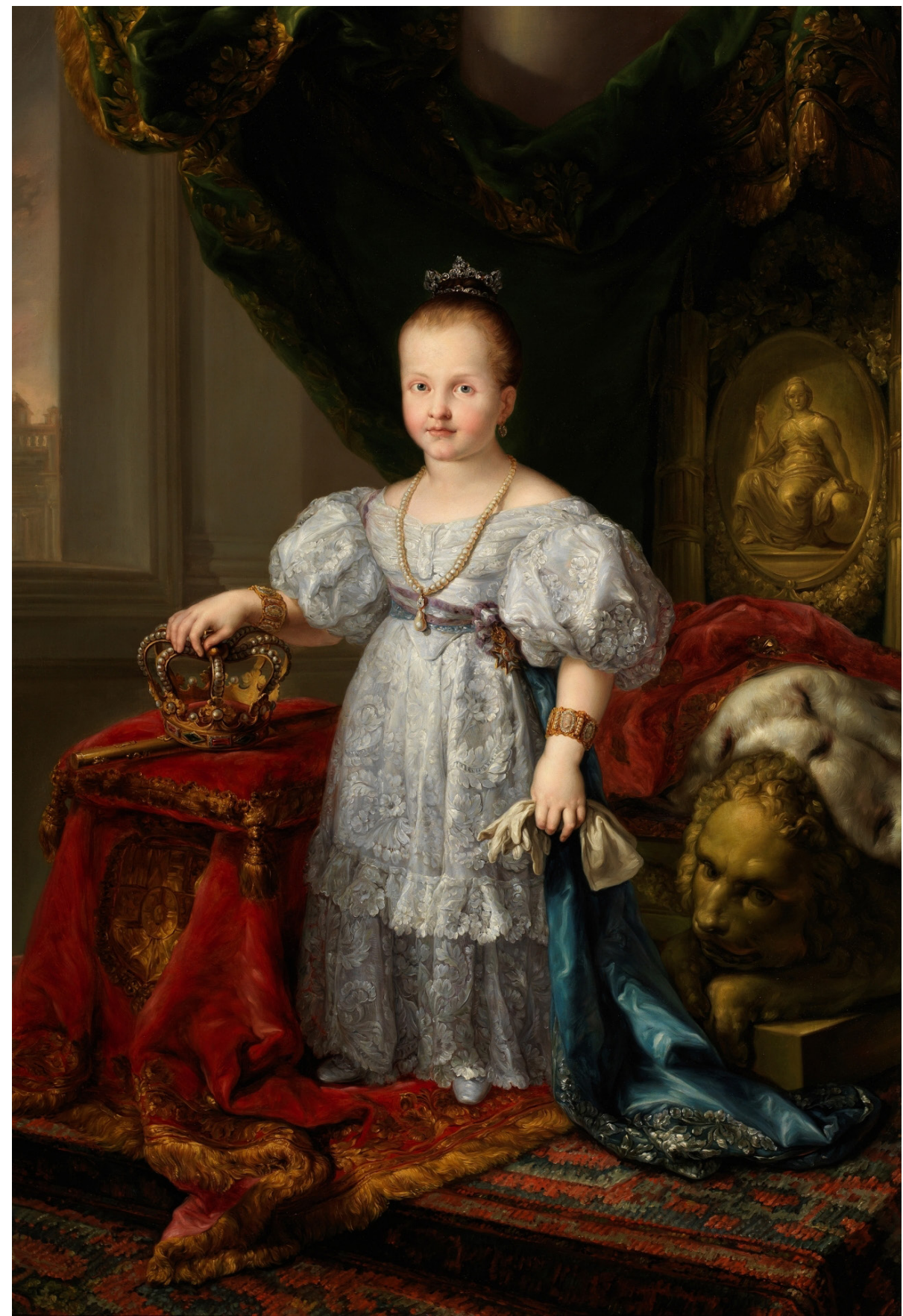

Isabel II niña, reina de España (1833-1868). Autor: Vicente López Portaña, hacia 1835. Museo del Prado. 
Ante el embarazo de María Cristina, Fernando VII y sus ministros más reformistas, enfrentados con los carlistas más absolutistas, decidieron asegurar la sucesión directa del rey derogando la Ley Sálica por medio de la Pragmática Sanción. La legitimidad de la Pragmática fue negada por los afines a don Carlos (Asensio, 2011, p. 41-43).

El 10 de octubre de 1830 nació Isabel, la hija primogénita de Fernando VII, la heredera al trono. Tres años después, el 29 de septiembre de 1833, falleció el monarca. Don Carlos, exiliado en Portugal, reivindicó sus derechos a la sucesión a la corona. El conflicto dinástico quedaba planteado. Los absolutistas más reaccionarios encuentran la excusa perfecta para alzarse en armas apoyando la causa de don Carlos. El conflicto desembocó en las tres guerras carlistas. La primera, que tuvo lugar entre 1833 y 1840, la segunda (1846-1849) y la tercera (1869$1876)^{3}$.

Socialmente, el carlismo fue un movimiento heterogéneo que recibió apoyos desde todos los órdenes sociales: campesinado, hidalguía, artesanado, oficiales del ejército, clero, etc. Una parte importante de la Iglesia, especialmente el clero rural, se vinculó al carlismo, reaccionando contra el anticlericalismo y las medidas secularizadoras que iban implantando los diversos gobiernos liberales (abolición del tribunal de la Inquisición, supresión de los diezmos eclesiásticos, disolución de ciertas congregaciones religiosas, desamortización eclesiástica, libertad de cultos religiosos, etc.). El lema que identificaba a los carlistas era "Dios, Patria y Rey", equivalente a la expresión "altar y trono": la relación indisoluble entre la divinidad y el poder político. El rey es rey por la gracia de Dios. El poder absoluto del monarca proviene de la voluntad divina.

Las tres guerras civiles asolaron todo el país. Puede decirse que no hubo ningún territorio español libre de partidas carlistas (Córcoles, 1999, p.159). Donde más fuerza y apoyo tuvieron los carlistas fue en Navarra, País Vasco, interior de Cataluña y el Maestrazgo (Teruel-Castellón). La provincia de Albacete, no se vio libre de estas guerras. Especialmente se vio afectada por la primera y la tercera.

\footnotetext{
${ }^{3}$ La mayoría de los historiadores fijan el inicio de la Tercera Guerra Carlista en 1872. Nosotros, al igual que M. Asensio, indicamos el año 1869, pues ya en estas fechas se producen actos armados protagonizados por carlistas en la provincia de Albacete y en Castilla La Mancha.
} 


\section{LA PRIMERA GUERRA CARLISTA EN LEZUZA Y SU COMARCA}

La provincia de Albacete, lugar de paso entre el centro de la Península y Levante, entre el Maestrazgo y Andalucía, va a ser frecuentada por las tropas carlistas y las fieles al ejército de la reina Isabel II. Hasta aquí llegaron las partidas guerrilleras procedentes del Bajo Aragón y del oeste de Valencia, más las facciones de Ciudad Real, que hicieron muy difícil la vida de los albaceteños en aquellos años de guerra. Poblaciones como Almansa, Alpera, Casas Ibáñez, La Roda, Villarrobledo, Alcalá del Júcar, Tarazona, Chinchilla, Nerpio, Elche de la Sierra, Letur, etc., sufrirían las acometidas de uno y otro bando. La provincia, recién creada en 1833 por las reformas de Javier de Burgos, sin rodaje administrativo, quedaba indefensa, abandonada a sus fuerzas, siendo presa fácil del carlismo para proveerse de víveres y recursos monetarios (Panadero, 2002, p. 13).

En la provincia de Albacete, y en especial en la capital, predominaron las ideas liberales (Córcoles, 1999, p. 160). No obstante, encontramos algunas localidades que destacaron por sus simpatías hacia las ideas carlistas. Tal es el caso de Villamalea, y especialmente El Bonillo y Ossa de Montiel (Panadero, 2002, p.13). Tenemos noticias de que en 1834, una partida carlista, al mando de Alfonso Campos, operaba por El Bonillo, cometiendo "toda clase de robos y exacciones". La mayoría de sus componentes eran naturales de esta población. El 5 de diciembre de ese mismo año fueron alcanzados en El Bonillo algunos de sus miembros por fuerzas isabelinas. Todos ellos fueron fusilados (Asensio, 2011, p. 92).

En julio de 1836, una facción de 80 carlistas invadieron otra vez el pueblo de El Bonillo y fusilaron al comandante de las fuerzas nacionales (Asensio, 2011, p. 211). Este mismo año, el 14 de noviembre, se dio aviso desde Balazote de que se había visto a la facción de Ramón Cabrera, el Tigre del Maestrazgo, con unos 800 hombres, "de ellos setecientos mal montados" (Córcoles, 1999, p. 166). Los militares carlistas, Cabrera y Gómez, poco tiempo atrás, el 19 de septiembre de 1836, fueron derrotados en Villarrobledo por el general Alaix (Roa 1891-94, p. 490; Córcoles, 1999, p. 163; Asensio, 2011, p. 223), por lo que es más que probable que los restos de su ejército fueran los que se vieron en Balazote, poco tiempo después, en situación lamentable.

En febrero de 1837, de nuevo la facción de Cabrera aparece en El 
Bonillo y "pide unas seis mil raciones, lo que provocó la huida de todas las autoridades". Poco después, en el mes de abril, en el mismo pueblo, la facción de Francisco Moreno, El Fraile, "cometió toda clase de excesos". Resultaron muertos dos facciosos. Terminando el año de 1837, "quince facciosos incendiaban el caserío de la Bediguilla", aldea perteneciente al término de Munera, de donde se llevaron como rehén a una mujer y a sus dos hijos, por cuyo rescate pidieron la cantidad de 15.000 reales (Asensio, 2011, p. 211-212).

Estas noticias de robos, secuestros, extorsiones, fusilamientos ..., alarmarían a las poblaciones de la comarca. En Lezuza, reunidos en noviembre de 1837 en el ayuntamiento, el alcalde y los regidores, dijeron "que estando cometiéndose en algunos pueblos de esta comarca varios destrozos, robos y crímenes, por los que se titulan facciosos", y con el fin de tomar medidas y prevenir lo que pudiera acontecer acuerdan "desde el día de mañana cerrar y cercar este pueblo por las partes que mejor sea y menos costoso". Cada yunta de mulas, bueyes y borriqueros "echarán tierra y piedra un día, cada jornalero trabajará un día [...] pagándoles los demás que echase"4.

En enero de 1838, el coronel carlista Antonio Tallada y Romeu, al frente de 2.300 infantes, 280 jinetes y 4 piezas de artillería se dirigía desde Iniesta (Cuenca) hacia Andalucía "a fin de conseguir caballos y suministros para su ejército" (Caridad, 2014, p. 514). En su camino pasó por La Roda, Barrax y Lezuza, y desde aquí se dirigió por El Ballestero hacia Alcaraz, para entrar en la provincia de Jaén. Fue derrotado varias veces en Andalucía, perdiendo la mayor parte de su ejército, que se disgregó en pequeños grupos emprendiendo la huida hacia Valencia y La Mancha. El coronel Tallada, con solo 30 o 40 hombres regresó hasta Barrax, donde se refugió en "la aldea de San Gerónimo, situada a un cuarto de legua de Barrax" ${ }^{5}$. Aquí fue capturado el día 6 de marzo de 1838 por milicianos nacionales del mismo pueblo (Sánchez, 2013, p. 109-111). Conducido hasta Chinchilla, se le juzgó en consejo de guerra, en el que se le condenó a la pena capital ${ }^{6}$. Fue fusilado el día 13

\footnotetext{
${ }^{4}$ Archivo Histórico Municipal de Lezuza (AHM Lezuza). Acta de la sesión de la corporación municipal de fecha: noviembre de 1837. (El alcalde era don Mariano Mendieta).

${ }^{5}$ Hoy conocida como Casa de Don Jerónimo, situada a 3 kms. al norte de Barrax.

${ }^{6}$ En enero de 1838, el coronel Tallada, en Iniesta, sorprendió a una pequeña columna de 250 soldados de la reina, que tras un breve combate se rindieron. Después, Tallada, mandó fusilar en Puente Carrasco (puente sobre el río Júcar, entre
} 


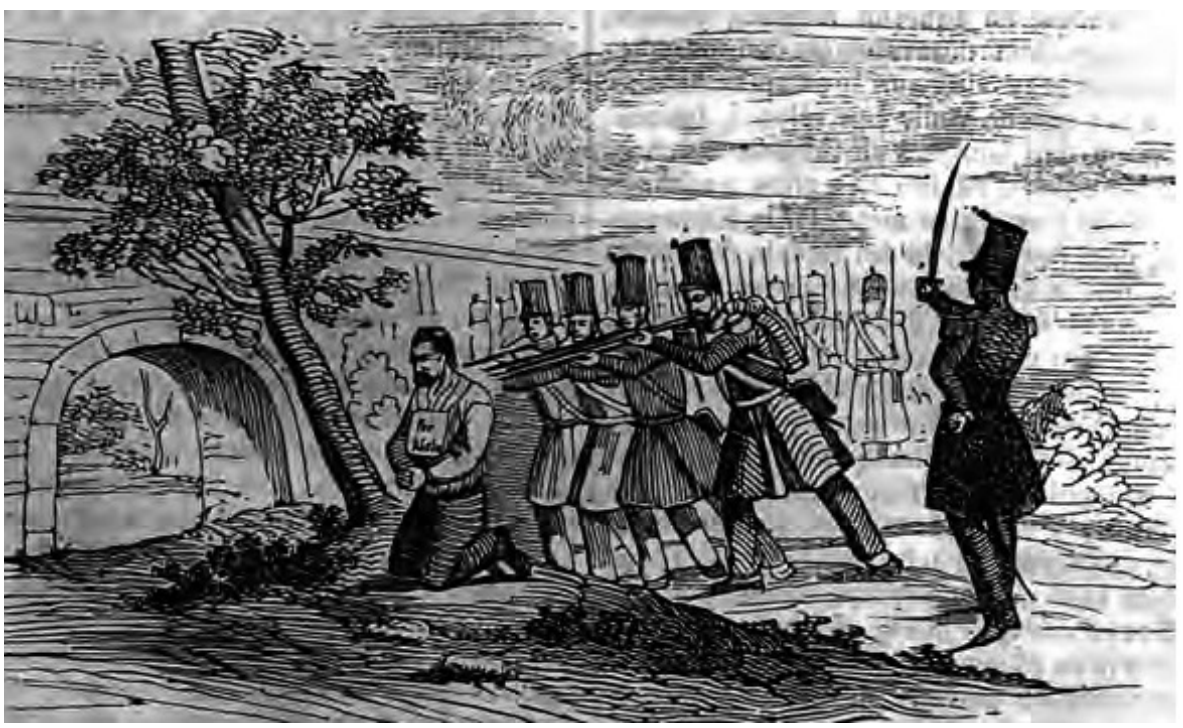

Fusilamiento del coronel Tallada en Chinchilla, 13 de marzo de 1838. (Caridad Salvador, 2014, p. 516).

de marzo, "a las cinco de la mañana, a la entrada de Chinchilla, en un azafranal" (Asensio, 2011, p. 224).

Los lezuceños no deberían de estar tranquilos con las noticias que les llegaban de los pueblos de alrededor, a pesar de haber mandado las autoridades "cerrar y cercar" la villa por miedo a las tropas carlistas. En el archivo parroquial de Ntra. Sra. de la Asunción de Lezuza, nos encontramos, que en el libro de defunciones, el cura, don Martín Trinidad Cantos, registra el día 31 de mayo de 1838 el fallecimiento de siete personas que pertenecían "al cuerpo de movilizados de esta provincia" y que fueron fusiladas "por la facción que invadió esta población el día de la fecha" (López-Torres, 1992, p. 127). En la documentación encontrada, el cura identifica los siete cadáveres y ordena darles sepultura en el cementerio de la localidad (ver tabla $\mathrm{n}^{\mathrm{o}}$ 1). Es probable que la facción carlista que atacó y llevó a cabo los fusilamientos en Lezuza fuera la misma que tres días antes, el 28 de mayo, asesinara en la Hoya del Pozo, cerca de La Gineta, a "doce milicianos para robar la diligencia

Tarazona de la Mancha y La Roda) al jefe de la columna, José Zeffel y a otros seis oficiales. Según los liberales, lo hizo sin motivo, e incumpliendo su promesa de respetar la vida de los prisioneros. Al parecer, esta fue la razón de la pena capital que le impuso el consejo de guerra que le juzgó en Chinchilla (Asensio, 2011, p. 224). 
que iba a Madrid” (Córcoles, 1999, p. 170). Según Sánchez Torres (1916, p. 38), la facción que actuó en La Gineta "parece estaba mandada por el cabecilla Archidona".

Tabla 1. Relación de fusilamientos “del cuerpo de movilizados de esta provincia" cometidos por los carlistas en Lezuza, el día 31 de mayo de $1838^{7}$

\begin{tabular}{|c|l|l|}
\hline Cadáver no & Nombre y apellidos & Origen \\
\hline 1 & Gerónimo Asenjo & Plasencia (ver doc. $\mathrm{n}$ ㅇ 1) \\
\hline 2 & Juan López & Yeste \\
\hline 3 & Rufino Cotillas & Yeste \\
\hline 4 & Ignacio Armero & Albacete \\
\hline 5 & Alfonso Blesa & La Gineta \\
\hline 6 & Bonifacio Palacios & Yeste \\
\hline 7 & Lorenzo Atencia & “de a cuatro leguas de las Peñas" \\
\hline
\end{tabular}

Según podemos observar en la tabla anterior, de los siete fusilados, uno era natural de Plasencia (Cáceres) y el resto había nacido en la provincia de Albacete. De la edad, no tenemos constancia. El cura anota en todos ellos "se ignora la edad". Lo que sí se repite en todos los casos es: "fue fusilado por la facción que invadió esta población". Por la tanto, es indudable que las tropas carlistas cometieron los asesinatos dentro del casco urbano de la villa, lo que amedrentaría todavía más, si cabe, a los lezuceños.

La comarca seguía amenazada por la incursión continua de carlistas. El 1 de julio de 1838 reaparece de nuevo la facción de Luis Archidona en Ossa de Montiel, donde fue derrotada por el 5ำ escuadrón de ligeros, dirigido por el comandante general de la provincia de Albacete, quedando en el campo de batalla, al menos, 50 muertos. Por estas mismas fechas, una partida acaudillada por León, hermano del asistente de Archidona, "robaba y saqueaba en la zona de Munera", pero perseguido por los nacionales del citado pueblo, resultaría muerto el cabecilla. (Asensio, 2011, p. 212, 214).

El acoso por parte de las partidas carlistas en la comarca era constante. El alcalde y los regidores del ayuntamiento de Lezuza, reunidos el 31 de agosto de 1838, toman conocimiento de las órdenes recibidas

${ }^{7}$ Archivo Histórico Diocesano de Albacete (AHDAB). Libro no 7 de Defunciones. LEZ 038, folios 94-95 vo. 
del comandante del batallón de la Milicia Nacional de La Roda, en las que se manda que "en caso de invasión o aproximación de la facción a este pueblo se retiren los Nacionales y demás pudientes a las Peñas, llevándose consigo las armas y los enseres que pudieran ser presa de la facción"s. Era evidente que el castillo de Peñas de San Pedro era un lugar más seguro para repeler los ataques y para proteger a los vecinos más acaudalados de los robos, secuestros y extorsiones que sufrían por parte de las tropas carlistas ${ }^{9}$.

$\mathrm{Al}$ año siguiente, en junio de 1839, Lino Calonge, que dirigía una sección del jefe carlista Palillos, fue muerto en Ossa de Montiel, a manos del ejército liberal.

El 31 de agosto de 1839, el Abrazo de Vergara puso fin a la primera guerra carlista en el norte de España, aunque las partidas de Cabrera y otras de Castilla La Nueva, continuarían con sus correrías por la provincia de Albacete, especialmente actuaron sobre la capital, La Roda y Villarrobledo.

A mediados de mayo de 1840, una partida de 47 facciosos invadía Villarrobledo y después se dirigió hacia Ossa de Montiel, donde sorprendieron a un extremeño, al que le quitaron un caballo y 50.000 reales. Después lo fusilaron. Además, también cometieron otros excesos "saciando su brutal apetito con las mujeres que van al campo y se llevaron caballerías, mantas y ropas de los caseríos ${ }^{10 "}$ (Asensio, 2011, p. 215).

El 26 de mayo de 1840, la facción de La Mancha, recientemente sublevada en Fernán Caballero (Ciudad Real), posiblemente la autora de los sucesos anteriores, va a coger prisioneros a cuatro carabineros de la Hacienda Nacional en Balazote, y al día siguiente "van a ser pasados por las armas dentro de la jurisdicción y término de Lezuza". (Ver doc. n⿳o 2). El nombre de los fusilados, la edad, la profesión, el origen y hasta el nombre de las viudas, lo conocemos a través de la documentación

\footnotetext{
${ }^{8}$ AHM de Lezuza. Acta de 31 de agosto de 1838. (El alcalde era don Juan Antonio Armero).

${ }^{9}$ No solo los de Lezuza utilizaban el castillo de Peñas para protegerse de las facciones carlistas. Tenemos constancia de que el 29 de junio de 1835 invadía la capital de Albacete la partida de Quílez, ante lo cual, las autoridades de Albacete se refugiaron en el castillo de Peñas de San Pedro. Lo mismo ocurre en octubre de 1848, ante la aparición de nuevas partidas carlistas (Asensio, 2011, p. 222, 229).

${ }^{10}$ Periódico El Castellano, no 1192, 28 de mayo de 1840, p.2. (Asensio, 2011, p.248).
} 
que se conserva en los libros parroquiales, donde el cura de Lezuza, don Martín Trinidad Cantos, anota estos datos y manda dar sepultura a los cadáveres (López-Torres, 1992, p. 127). Lo podemos ver en la tabla siguiente.

De la tabla anterior destacamos que de los cuatro carabineros Tabla 2. Relación de carabineros fusilados por la facción de La Mancha, en Lezuza, el día 27 de mayo de $1840^{11}$

\begin{tabular}{|c|l|c|l|l|}
\hline No & \multicolumn{1}{|c|}{$\begin{array}{c}\text { Nombre } \\
\text { y apellidos }\end{array}$} & Edad & \multicolumn{1}{|c|}{ Origen } & \multicolumn{1}{|c|}{ Viuda } \\
\hline 1 & Francisco Vicente & 34 & Valencia & Josefa Rivera \\
\hline 2 & Pascual Palacios & 36 & Tarazona de la Mancha & Juana Sánchez \\
\hline 3 & José Antonio Romero & 32 & Alhama de Murcia & Juana Caulín \\
\hline 4 & Diego Cebrián & 30 & Albacete & Soltero \\
\hline
\end{tabular}

fusilados, uno era natural de Valencia, otro de la provincia de Murcia, siendo los otros dos de la provincia de Albacete. Todos ellos eran muy jóvenes, el de más edad tan solo contaba con 36 años, siendo el menor de 30 años, el único que estaba soltero ${ }^{12}$. Los fusilamientos se produjeron dentro del término de Lezuza, aunque el cura no especifica dónde. Lo que sí es incuestionable es que fueron enterrados en el cementerio de la villa. Hacía dos años, en mayo de 1838, los carlistas fusilaban dentro de la población a siete personas, que unidos a estos cuatro enterramientos, alarmarían en alto grado a los vecinos, causando miedo y terror ante posibles nuevas invasiones de partidas carlistas.

Pocos días después, en junio de 1840, el almagreño Vicente Rugero, apodado Palillos, con una facción compuesta de 150 caballos, procedente de Aragón, entraba en "la vega de Lezuza", con el objeto de reunirse con el escuadrón sublevado de salvaguardias de La Mancha, mandado por los Saturnos, los cuales, a su vez, recorrían la zona de Balazote causando graves perjuicios en la época de la recolección (Asensio, 2011, p. 225). Esta información, junto con la documentación hallada en la parroquia de Lezuza, nos hace deducir que la partida que fusiló

\footnotetext{
${ }^{11}$ ADA. LEZ 038, Folios 123, 123 vo. Además del cura, don Martín Trinidad Cantos, firman como testigos don Mariano Mendieta, don José Martínez Jiménez y el clérigo tonsurado don Antonio Tendero, "naturales todos y vecinos de esta villa" (cadáver no 1 ).

${ }^{12}$ Por la cantidad de información que aporta el cura en el Libro de Defunciones, intuimos que los datos los obtiene de las cédulas personales que llevarían en sus uniformes.
} 
a los cuatro carabineros en Lezuza fue la que dirigían los Saturnos, la denominada "facción de La Mancha", y que estaba causando estragos por la comarca, en concreto en Ossa de Montiel, Balazote y Lezuza.

La partida de Palillos fue la más destacada a favor de la causa legitimista de don Carlos V de Borbón en Castilla La Nueva, durante la primera guerra. Estaba dirigida por Vicente Rugero y su hermano Francisco, naturales de Almagro (Ciudad Real). Llegó a juntar más de 500 hombres que combatieron de forma despiadada. La mayoría eran voluntarios civiles y con escasa preparación militar (Pérez, 2011, p. 4-19).

Pío Baroja, en su novela La nave de los locos (1980, p. 283-285) nos dibuja una semblanza del bandolero Palillos, donde nos revela datos muy interesantes de su cuadrilla y de la manera de actuar cuando llegaban a los pueblos. Por su interés, lo transcribimos a continuación:

[...] Palillos ha sido muy famoso. [...] Palillos padre, don Vicente Rugero, era un viejo muy ladino. Tenía una partida muy bien organizada y muy militar. Ya lo creo. Y no piense usted que era fácil entrar en ella [...] Para entrar en la partida se necesitaban muchas condiciones. Había que tener menos de treinta años, ser fuerte, buen caballista, estar acostumbrado a la vida del campo y no tener parientes ni amigos entre los cristinos. [...] Cuando Palillos se proponía sacar contribuciones en una comarca, dividía su caballería en partidaSD de treinta a cuarenta hombres; ocupaban todos los lugares en un espacio de seis a ocho leguas cuadradas. Cada paisano debía suministrar todo lo necesario para un jinete y un caballo. Los pueblos se veían obligados a entregar a Palillos la misma contribución que pagaban al Gobierno de la reina. Entrábamos nosotros en un lugar, y lo primero, para que nadie tocase a rebato y diera señal de alarma, nos apoderábamos de la torre de la iglesia y poníamos en el campanario un centinela. El centinela observaba cuanto pasaba a larga distancia, y si veía algo tocaba la campana, y, según las campanadas, nos entendíamos. Era como la línea del telégrafo de señales del Gobierno. Así, don Vicente Rugero sabía con rapidez si aparecía el enemigo y por dónde .

Después de junio de 1840, ya no volvemos a tener noticias de actuaciones carlistas en la comarca de Lezuza. Al terminar la primera guerra, un gran número de dirigentes y miles de simpatizantes del carlismo pasarían a Francia.

A partir de 1846, se inicia en Cataluña el movimiento conocido 


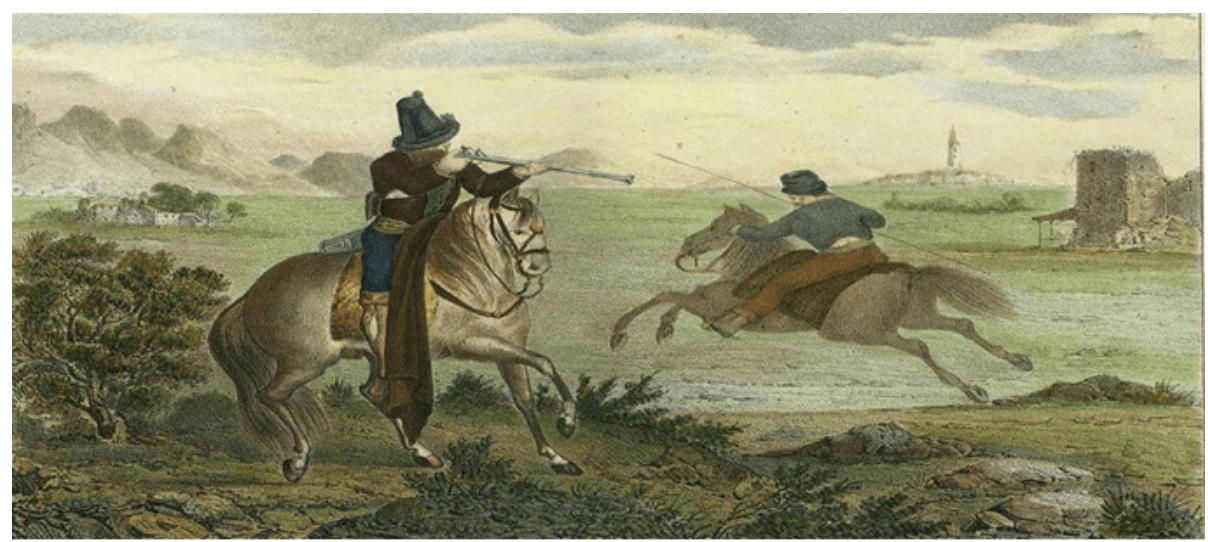

Estampa titulada “Caballería del Cid”, de la que formaba parte la facción de Palillos ${ }^{13}$.

como "dels matiners", empezando así la Segunda Guerra Carlista (18461849), que se extendió a la zona vasco-navarra, Castilla La Vieja, Extremadura y Castilla La Nueva. En nuestra región afectó especialmente a las provincias de Ciudad Real y Toledo, y mínimamente a la de Albacete; aunque algunas poblaciones sí sufrieron los efectos de las partidas carlistas, como La Roda, Casas Ibáñez, Casas de Ves, Jorquera, Carcelén, Alpera y la propia capital, Albacete (Asensio, 2011, p. 53, 228, 229).

\section{LOS DOCUMENTOS DE 1874 ENCONTRADOS EN EL JUZGADO DE PAZ}

En el Juzgado de Paz de Lezuza se han conservado ocho documentos fechados el 27 de diciembre de 1874. En ellos, el secretario del juzgado, don José María González, identifica a ocho cadáveres que pertenecían a "la facción que acaudillaba el conocido como cura de Alcabón, don Lucio Dueñas", que fue sorprendida en la aldea de Pradorredondo (Lezuza), "por la columna del Teniente Coronel Portillo", oficial que dirigía las tropas del ejército liberal. Los documentos hacen mención a

\footnotetext{
${ }^{13}$ Estampa que representa a la Caballería del Cid. En la parte inferior de la estampa aparece el siguiente texto: "Caballería del Cid. Tres escuadrones. Su fuerza: 250 caballos formados por los restos de Tallada; un escuadrón de la gente que reunieron en La Mancha los partidarios de la Diosa, Peco y Palillos; y otros cuantos caballos que se denominaban Cosacos del Tajo. No habiendo uniformidad alguna de su modo de vestir. La estampa los representa en sus diversos trajes".

(En línea. Consulta: 29/03/2020. Disponible en: https://www.tradicionviva. es/2017/01/02/palillos-un-guerrillero-carlista-en-la-mancha/).
} 
que murieron en el combate 120 carlistas, que fueron enterrados en tres fosas comunes: "el pozo de los 52", "la fosa que contiene cincuenta y siete" y "la fosa consecutiva de los once" 14 .

El secretario va describiendo, uno a uno, los cadáveres de los fallecidos. Un resumen se plasma en la tabla siguiente:

Tabla no 3. Relación de ocho cadáveres correspondientes a soldados carlistas que pertenecían a la facción del cura de Alcabón. Pradorredondo, 27 de diciembre de 1874

\begin{tabular}{|l|l|c|l|l|}
\hline No & $\begin{array}{l}\text { Identificación } \\
\text { (nombre) }\end{array}$ & Edad & Origen & Otros datos \\
\hline 1 & $\begin{array}{l}\text { Romualdo García } \\
\text { Monsalvo }\end{array}$ & 43 & $\begin{array}{l}\text { Tarancón } \\
\text { (Cuenca) }\end{array}$ & $\begin{array}{l}\text { "dijo tener un hijo llamado } \\
\text { Gregorio García" }\end{array}$ \\
\hline 2 & Un sacerdote & 36 a & $\begin{array}{l}\text { Villagar-cía } \\
\text { (Cuenca) }\end{array}$ & $\begin{array}{l}\text { "grueso, color blanco, abul- } \\
\text { tado de cara, con entradas } \\
\text { en la cabellera [...] se ha- } \\
\text { lló cadáver en la senda de } \\
\text { Fuentepinilla" }\end{array}$ \\
\hline 3 & Anónimo & $\begin{array}{c}18 \text { a } \\
20\end{array}$ & Sin especificar & $\begin{array}{l}\text { "pelo negro, color al pare- } \\
\text { cer bueno, estatura regu- } \\
\text { lar [...] fue sepultado en el } \\
\text { pozo de los 52" }\end{array}$ \\
\hline 4 & Anónimo & 51 & $\begin{array}{l}\text { Alcázar de San } \\
\text { Juan }\end{array}$ & $\begin{array}{l}\text { "según manifestación de } \\
\text { un aldeano de ésta [...] era } \\
\text { natural de Alcázar de San } \\
\text { Juan y de estado casado". }\end{array}$ \\
\hline 5 & Alejandro Ocón & 30 & $\begin{array}{l}\text { Alcázar de San } \\
\text { Juan }\end{array}$ & $\begin{array}{l}\text { "casado con Ángela Alami- } \\
\text { nos [...] dijo tener hijos". }\end{array}$ \\
\hline 6 & Demetrio Giménez & $\vdots ?$ & Yepes (Toledo) & $\begin{array}{l}\text { "hijo de Juany Dorotea Cuer- } \\
\text { vo [...] antecedentes que } \\
\text { antes de morir facilitó a los } \\
\text { aldeanos de Pradorredondo } \\
\text { [...] fue sepultado en la fosa } \\
\text { de los cincuenta y siete" }\end{array}$ \\
\hline
\end{tabular}

\footnotetext{
${ }^{14}$ Los documentos que se conservan son ocho "papeles sueltos", tamaño cuartilla, que están en el Tomo 3ํㅡㄹ de defunciones, folio 67, del Registro Civil de Lezuza, junto a la inscripción no 124 de un niño de un mes de edad, que falleció el 23 de diciembre de 1874. El secretario era don José María González; el juez de paz, don Juan García Mendieta.
} 


\begin{tabular}{|l|l|c|l|l|}
\hline 7 & $\begin{array}{l}\text { Antonio Guarasa y } \\
\text { Ramírez }\end{array}$ & 27 & $\begin{array}{l}\text { Fuenca-liente } \\
\text { (C. Real) }\end{array}$ & $\begin{array}{l}\text { "sepultado en la fosa con- } \\
\text { secutiva de los once carlis- } \\
\text { tas" }\end{array}$ \\
\hline 8 & $\begin{array}{l}\text { Romualdo Clemente } \\
\text { Aparicio }\end{array}$ & 42 & Toledo & $\begin{array}{l}\text { "barba negra, estatura de } \\
\text { unos cinco pies, con una ci- } \\
\text { catriz grande en la frente" }\end{array}$ \\
\hline
\end{tabular}

De los 120 carlistas muertos, que son los que suman las tres fosas comunes donde los enterraron, tan solo disponemos información de ocho de ellos. Cinco son identificados por su nombre, de dos sabemos su procedencia, y de otro, únicamente su edad aproximada y descripción física. Estudiando su origen, podemos decir que todos eran manchegos. Tres de ellos habían nacido o provenían de la provincia de Ciudad Real, dos de la provincia de Toledo y otros dos de Cuenca. Ninguno era natural de la provincia de Albacete. En un caso, desconocemos su ascendencia. Analizando su edad, tres de ellos tenían más de 40 años, otros tres habían superado los 25, y uno no había cumplido los 20. También aparece otro registro en el que no se especifica la edad. La media de edad de los cadáveres registrados asciende a 35 años, lo que nos lleva a presuponer que la partida estaría formada por guerrilleros con bastante experiencia.

Es interesante examinar el contenido de cada uno de los registros (ver en el apéndice el doc. no 3). Así, el cadáver no 2 corresponde a "un sacerdote como de 36 a 40 años, grueso, color blanco, el cual se hallaba desnudo excepto de la camisa que era de hilo, abultado de cara, con entradas en la cabellera y nariz abultada". Incluso leemos que se lo encontraron muerto en "la senda de Fuentepinilla" y era natural "de Villagarcía, del partido de Motilla del Palancar". Actualmente, los vecinos de Pradorredondo conocen un lugar, en el camino de Fuentepinilla ${ }^{15}$ a El Ballestero, donde existe una gran piedra con una cruz grabada, a la que llaman la cruz del cura. Recuerdan, que en este lugar se encontraron a un cura muerto "cuando lo de los carlistas".

Por otro lado, hemos de observar algunas circunstancias que refleja el escribano del juzgado y que serán muy esclarecedoras para precisar otros informes que después analizaremos. En el cadáver no 6, escribe: "Demetrio Giménez, natural de Yepes, hijo de Juan y Dorotea Cuervo. Ante-

${ }^{15}$ La "cruz del cura" está a dos kilómetros de Pradorredondo, en el camino que conduce hacia Fuentepinilla (aldea del municipio de Lezuza). 


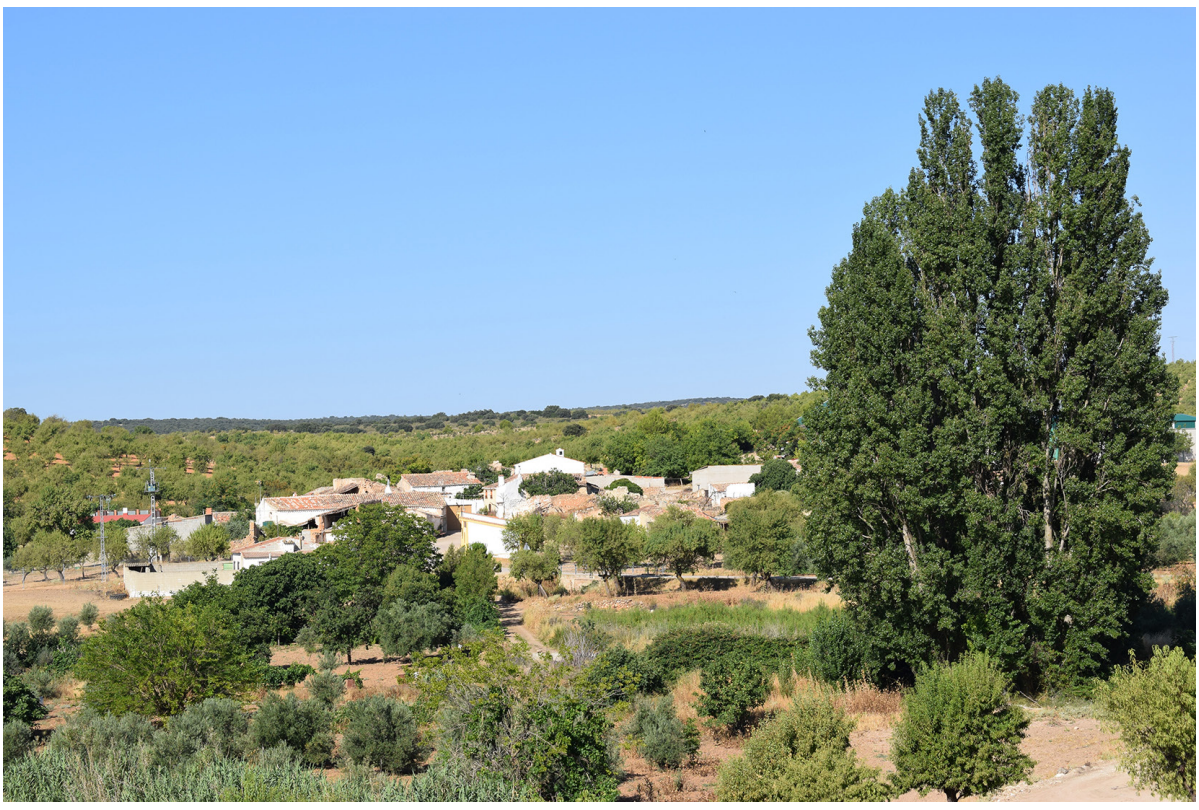

Pradorredondo, aldea situada a 2 kms. de Tiriez (Lezuza). Foto: J. A. Munera.

cedentes que antes de morir facilitó a los aldeanos de Pradorredondo". Y en el cadáver no 4, leemos: "y según manifestación de un aldeano de esta [...] era natural de Alcázar de San Juan". Las afirmaciones anteriores dejan claro que, al menos, estos carlistas muertos habían mantenido contacto verbal con los vecinos de Pradorredondo, pues llegaron a conocer sus nombres, e incluso el de sus hijos, o su lugar de residencia.

También encontramos expresiones, como "dijo tener hijos" (cadáver no 5), o "dijo tener un hijo llamado Gregorio" (cadáver no 1), que denotan, o bien conocimiento por parte de los aldeanos, o también, y es lo más probable, que quedaron supervivientes carlistas que colaboraron en la identificación de los cadáveres de sus compañeros.

\section{DON LUCIO DUEÑAS, EL CURA DE ALCABÓN}

Don Lucio Dueñas, el cura que dirigía la partida de carlistas en Pradorredondo, nació en 1817 en Torrijos (Toledo). Desde muy joven, y hallándose todavía en el seminario de Toledo, ya destacaba por sus ideas a favor de la causa del pretendiente Carlos María Isidro de Borbón (Carlos V) y "llevaba municiones a los carlistas durante la primera guerra civil” (Espasa, 1920, p. 2382). 


\subsection{Participación en “La Ortegada”, 1860}

Mientras ejercía de cura en el pueblo de Cercadillo (Sigüenza-Guadalajara), desde el púlpito se encargaba de enardecer a la población en contra de Isabel II. El 2 de abril de 1860 participó en la conspiración de San Carlos de la Rápita (Tarragona), la conocida como "la Ortegada", cuando el general Jaime Ortega y Olleta, con el apoyo expreso del cardenal arzobispo de Toledo, organizaron un complot para proclamar al pretendiente carlista Carlos Luis de Borbón (Carlos VI) como legítimo rey de España, y destronar a Isabel II. El complot fracasó y el general Ortega fue fusilado. Don Lucio Dueñas consiguió huir y se refugió en Cercadillo. Poco después, el 23 de abril de 1860, don Lucio sería detenido, procesado por sedición y condenado a pena de cárcel en Sigüen$\mathrm{za}^{16}$. Posteriormente sería amnistiado y puesto en libertad ${ }^{17}$ (Espasa, 1920, p. 2382).

\subsection{Organiza la primera partida de carlistas siendo cura de Alca- bón y es encarcelado en Menorca}

Una vez recuperada la libertad, ejerció como cura ecónomo en la parroquia de Alcabón (Toledo), localidad que está a 8 kilómetros de Torrijos, su pueblo natal. En Alcabón seguirá defendiendo los ideales del carlismo, bajo la consigna ya expresada de "Dios, Patria y Rey", que sintetiza la defensa de una monarquía católica y tradicional de corte absolutista.

Un buen día de 1869, con 52 años, con "un caballo prestado", abandonó la parroquia de Alcabón, "se le vio dejar el sombrero de copa y el alzacuello poniéndose una boina", reclutó a 40 hombres de diversos pueblos y se refugió en las sierras del norte de la provincia de Toledo ${ }^{18}$. Con la partida de guerrilleros que llevaba se dedicaba al saqueo y pi-

\footnotetext{
${ }^{16}$ Atienza de los Juglares: “Sucedió en abril”, abril de 2013, p. 29. Dirección y coordinación: Tomás Gismera Velasco. (En línea. Consulta: 12/02/2020). Disponible en: https://es.calameo.com/read/0001485518737db26fd20).

${ }^{17}$ Se acogería a la amnistía aprobada por el Gobierno el 1 de mayo de 1860. "amnistía a toda persona procesada, sentenciada o sujeta a responsabilidad por cualquier clase de delitos políticos" (Herrero, 2012, p. 163).

${ }^{18}$ La Correspondencia de España, no 4278. Madrid, 8 de agosto de 1869.

Todas las referencias a prensa histórica, si no se especifica otra, han sido consultadas en la siguiente dirección:

https://prensahistorica.mcu.es/es/consulta/resultados_ocr.do
} 


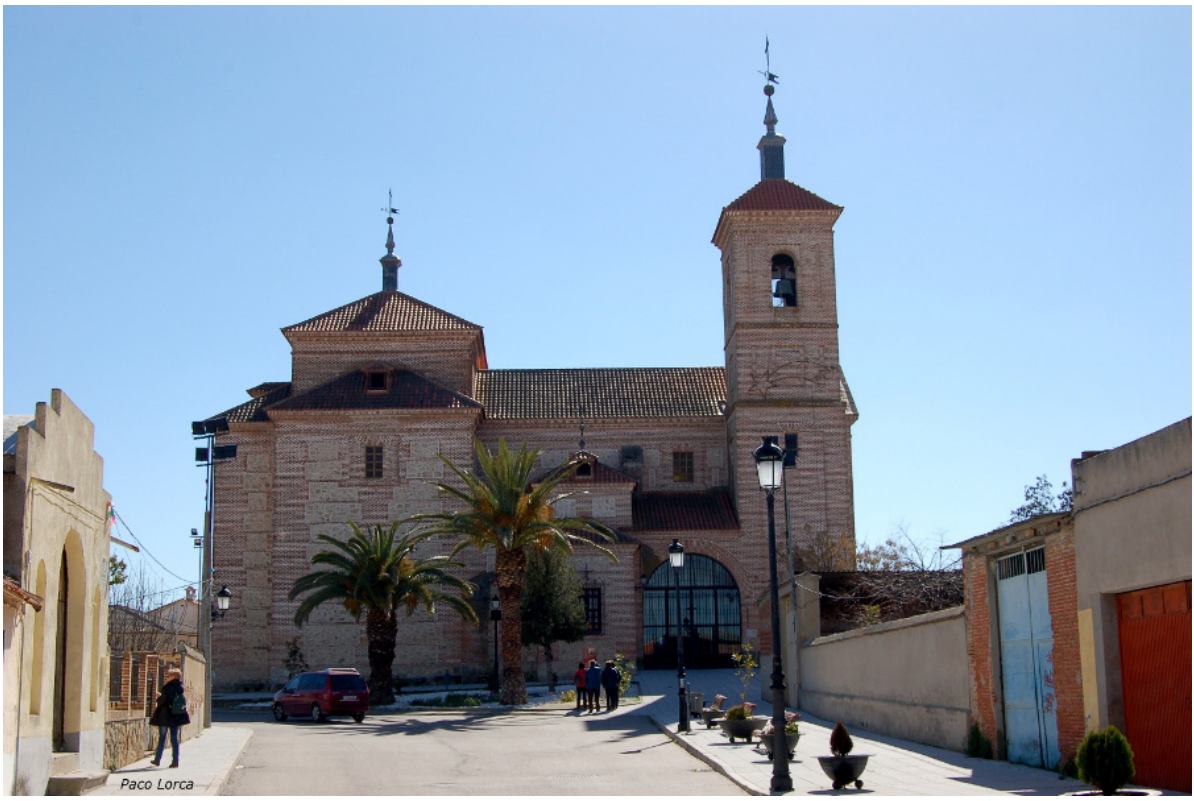

Iglesia de Alcabón (Foto actual). ${ }^{19}$ Don Lucio Dueñas fue cura ecónomo de esta parroquia.

llaje en los pueblos de la provincia por los que circulaba (Cardiel de los Montes, Maqueda, Escalona, Malpica de Tajo, Nombela, Santa Cruz del Retamar, Velada, Montes Claros, Iglesuela, etc.) e incluso alguno de los limítrofes con la provincia de Madrid, como es el caso de Cenicientos.

La incautación de fondos de los ayuntamientos y de los recaudadores de contribuciones, el secuestro de rehenes para la obtención de rescate, el asalto a diligencias, el robo de ganados y caballerías, el incendio de archivos en registros civiles y juzgados, sabotajes a líneas de telégrafos y vías férreas..., eran las tropelías más corrientes que cometían las partidas carlistas (Asensio, 2011, pp. 343-346), y también las que llevaba a cabo la partida del cura de Alcabón. El objetivo era obtener fondos y víveres para la causa, y hacer el mayor daño posible a los estamentos oficiales dependientes del Gobierno. La Guardia Civil y el ejército iban tras sus pasos.

En agosto de 1869, la facción de 40 hombres que dirigía el cura de Alcabón, hombre "de baja estatura, grueso cuerpo, cara enjuta y mirada penetrante y viva" sería avistada y disuelta por el teniente de la guardia civil, Sr. Carsi, en Iglesuela de Tiétar (Toledo) ${ }^{19}$. El cura fue

${ }^{19}$ La Correspondencia España, no 4272. Madrid, 2 de agosto de 1869. 


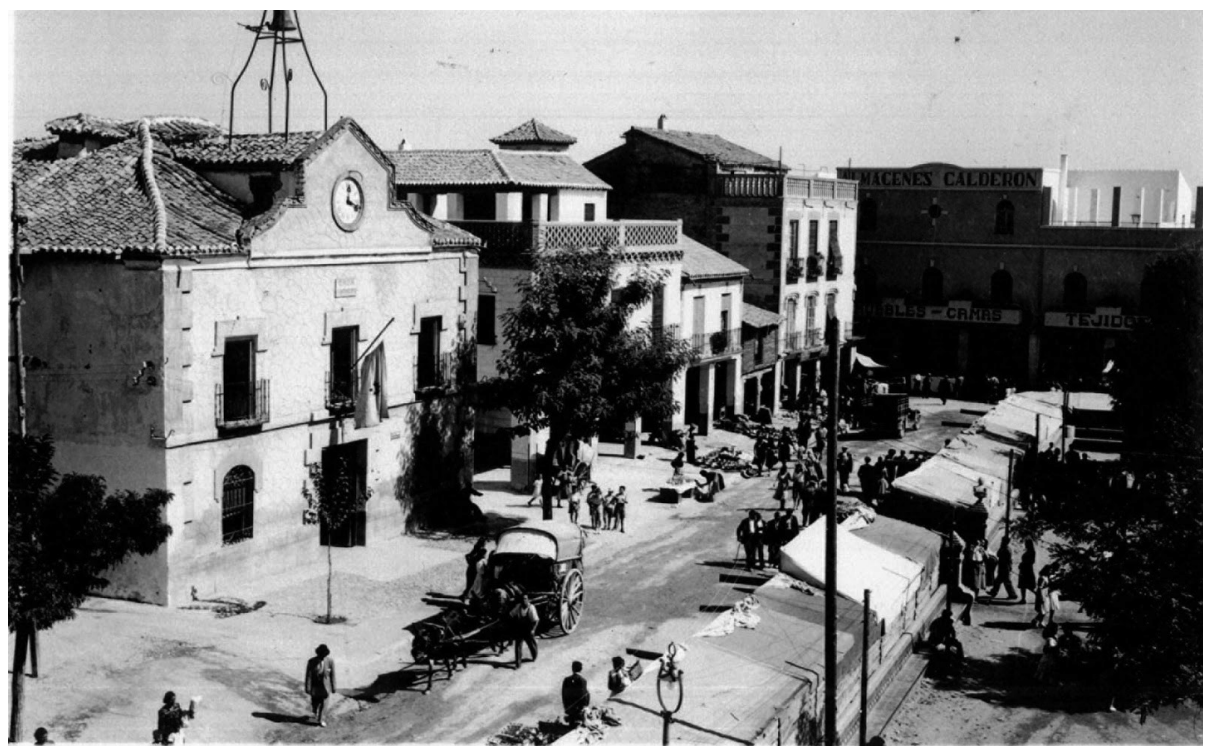

Plaza y ayuntamiento de Torrijos, hacia 1957. Torrijos era el pueblo de nacimiento del cura de Alcabón. (Foto: Archivo Municipal de Torrijos). ${ }^{20}$

detenido junto a otros dos individuos, uno de ellos "un estudiante del seminario". Todos ellos serán trasladados a Toledo, donde la popularidad del sacerdote congregó a "un gentío inmenso" cuando llegaron a la ciudad. Después fueron conducidos a la cárcel.

Don Lucio fue juzgado por un delito de rebelión. El juzgado de Torrijos lo condenará a 20 años de cárcel, sentencia que fue revisada por la Audiencia de Madrid, que rebajó la condena a 12 años ${ }^{21}$. Fue trasladado el 2 de abril de 1870 hasta Mahón (Menorca), a la prisión de La Mola, para cumplir la pena. Así lo reseñaba la Crónica de Menorca: "hoy debe llegar a esta capital por tránsitos de justicia, don Lucio Dueñas, cura de Alcabón"n2. Posteriormente se acogería a medidas de gracia del Gobierno y, el 14 de julio de 1870, tenemos constancia de que la pena de presidio le había sido conmutada por la del destierro. La guardia civil lo trasladó desde Santoña (Cantabria), lugar donde estaba encarcelado, hasta

\footnotetext{
${ }^{20}$ En Línea. Consulta: 08/04/2020. Disponible en: http://archivotorrijos.blogspot.com/2015/07/remodelacion-del-antiguo-ayuntamiento.html

${ }^{21}$ La Correspondencia de España, no 4461 y 4479. Madrid, 8 y 26 de febrero de 1870.

${ }^{22}$ La Crónica de Menorca, no 53.2 de abril de 1870.
} 
la frontera francesa, pasando por Bilbao y San Sebastián ${ }^{23}$. En Bayona y Burdeos cumplió el destierro (Pirala, 1892, vol. II, p. 582).

\subsection{Organiza la segunda partida carlista tras su destierro en Francia}

No habían transcurrido dos años desde que cruzó la frontera francesa y en abril de 1872 volvemos a tener noticias de que "el cura de Alcabón se ha levantado en armas con una partida en La Mancha". Entre los que le acompañaban figuraban "algunos criados de personas muy conocidas en los distritos de Torrijos y Escalona"24.

Con una partida que oscilaba entre 40 y 50 jinetes, "el cura que ha sido indultado dos veces" recorre numerosos pueblos como Villarta de Escalona, Albarreal de Tajo, Novés, Hormigos, Santa Olalla, etc., todos ellos de la provincia de Toledo, realizando robos de caballos, armas y aprovisionándose de alimentos ${ }^{25}$.

A mediados de mayo de 1872, la partida sufre un serio revés en San Bartolomé de las Abiertas (Toledo), a manos de la columna que dirigía el teniente coronel de la guardia civil, don Juan Pastor, que logró batir y poner en fuga a la facción, "causándole cuatro muertos, dos heridos, cuatro prisioneros y apresándole siete caballos y varias armas y efectos". Se dio la partida de don Lucio "por disuelta y en completa derrota". Poco después fue vista la facción en Retuerta del Bullaque (Ciudad Real) reducida a 13 individuos ${ }^{26}$.

\subsection{Se unen las facciones de Mulita, Bermúdez y el cura de Alcabón}

A finales de mayo de 1872, sabemos que Francisco Bermúdez actúa como titular de la comandancia de Toledo, y se encarga de reunir las partidas de Toledo y Ciudad Real. Junto a la de Bermúdez, se unieron los guerrilleros dirigidos por Félix Alonso Quirós "Mulita" y los del cura de Alcabón, que sumaban un total de 80 hombres (Asensio, 2011, p. 103). Esta conjunción de fuerzas se dejarían caer por Villarrubia de los Ojos y Malagón en la provincia de Ciudad Real; por Guadalerzas,

\footnotetext{
${ }^{23}$ La Correspondencia España, no 4416. Madrid, 14 de julio de 1870.

${ }^{24}$ La Lucha, no 244. Gerona, 26 de abril de 1872.

La Correspondencia, no 5278. Madrid, 10 de mayo de 1872.

${ }^{25}$ La Independencia Española, no 961. Madrid, 8 de mayo de 1872.

La Correspondencia de España, no 5277. Madrid, 9 de mayo de 1872.

${ }^{26}$ La Correspondencia de España, no 5282 y 5286. Madrid, 14 y 16 de mayo de 1872.

El Constitucional, diario liberal, no 174. Alicante, 16 de mayo de 1872.
} 
Gálvez, Puebla de Montalbán y Fuensalida en Toledo; y llegarían hasta la provincia de Badajoz, a Herrera del Duque y a Siruela, en esta última robarían 3.000 reales $^{27}$.

Huyendo del ejército y de la Guardia Civil llegaron hasta la Estación de Algodor (Aranjuez), donde detuvieron el tren correo "y registraron los equipajes de los viajeros, tomando algunas armas y efectos [...] inutilizaron los hilos del telégrafo y sus aparatos" y después siguieron por la provincia de Toledo en dirección a Mora. A continuación, entraron en Gálvez con 120 caballos "exigiendo 140 raciones de pan, 15 fanegas de cebada y algunas armas", acercándose después hasta la Puebla de Montalbán ${ }^{28}$.

Los pueblos por los que circulaban las partidas carlistas estaban alarmados por las continuas tropelías y desmanes que sufrían. Ante el malestar de la población, el diario La Independencia (Madrid) se quejaba de que el gobierno del Sr. Ruiz Zorrilla"29 "manda en toda España menos en La Mancha. En esa región comparte sus tareas con el nunca bien ponderado cura de Alcabón”, y se pregunta: “¿Es imposible echarle el guante?" Igualmente el periódico Crónica de Badajoz, "urge ciertamente a que se le dé su merecido al tal cura [...] por no haber renunciado a manejar el trabuco y encasquetarse la boina" a pesar de haberse acogido a la última amnistía ${ }^{30}$.

Pero todo no eran asaltos a pueblos y huidas apresuradas. La partida también gozaba de sus ratos de asueto y diversión. En Urda (Toledo), según cuentan, "el cura de Alcabón en los ratos de ocio visita las tabernas de los pueblos por donde pasa [...] y bebió de lo lindo y brindó por Carlos VII, [...] solo le falta el ama al lado"31.

A últimos de junio de 1872, la columna del teniente coronel Cor-

\footnotetext{
${ }^{27}$ La Correspondencia de España, no 5290, 5299, 5300, 5306 y 5311. Madrid, 22 y 31 de mayo, 1, 7 y 12 de junio de 1872 (respectivamente).

La Independencia Española, no 977. Madrid, 29 de mayo de 1872.

La Unión Republicana, no 299. Palma de Mallorca, 29 de julio de 1897.

${ }^{28}$ La Correspondencia de España, no 5313. Madrid, 14 de junio de 1872.

El Constitucional, diario liberal, no 198. Alicante, 14 de junio de 1872.

${ }^{29}$ Manuel Ruiz Zorrilla fue Presidente del Gobierno en dos ocasiones: julio a octubre de 1871; y desde junio de 1872 a febrero de 1873. Dimitió en febrero de 1873 al no conseguir que el rey Amadeo I de Saboya no renunciara a la corona. El 11 de febrero de 1873 se proclamó la I República.

${ }^{30}$ Crónica de Badajoz, no 609. Badajoz, 18 de junio de 1872.

La Independencia Española, no 998. Madrid, 24 de junio de 1872.

${ }^{31}$ La Independencia Española, no 993. Madrid, 18 de junio de 1872.
} 


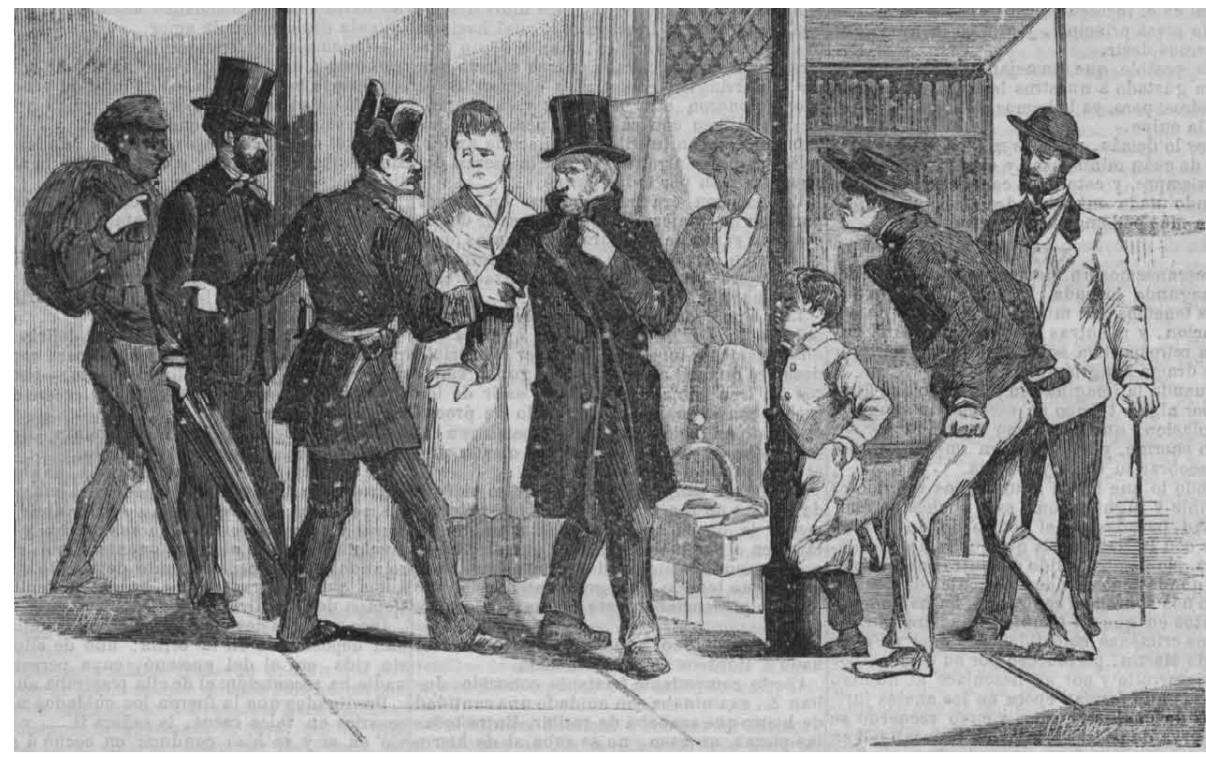

Don Lucio Dueñas, el cura de Alcabón, es apresado en julio de 1872 en Madrid, en la calle del Arenal. (Dibujo publicado en El periódico para todos. Talleres de Impresión: Zaragozano y Jayme. Madrid, 1872).

tijo va a alcanzar en el Puerto de Honduras, al norte de la provincia de Cáceres, al grupo guerrillero de Bermúdez y del cura de Alcabón, "causándole 13 muertos, muchos heridos y cogiéndoles armas y caballos". Don Lucio, tan escurridizo como siempre, consiguió escapar. Se le volvió a ver a principios de julio en Madridejos (Toledo) con su partida muy debilitada ${ }^{32}$.

\subsection{Es apresado en Madrid y desterrado a Cuba}

Un mes después, el 30 de julio de 1872, "el celebérrimo cura de Alcabón", cuando estaba comprando un traje en la calle del Arenal, de Madrid, pues "la ropa que llevaba estaba totalmente destrozada", va a ser identificado y apresado ${ }^{33}$. Será conducido a la cárcel del Saladero ${ }^{34}$. Aunque la mayoría de los periódicos madrileños se felicitan por la captura del afamado cura, también los hay que dicen que "es un delincuente

${ }^{32}$ La Correspondencia de España, no 5329 y 5338. Madrid, 30 de junio y 9 de julio de 1972.

${ }^{33}$ Según Antonio Pirala (1892, vol. II, p. 583), fue a Madrid "disfrazado de arriero y montado en un burro con dos canastas de fruta" con intención de dirigirse hacia el Norte.

${ }^{34}$ La Independencia Española, no 1029 . Madrid, 31 de julio de 1872. 
político, un hombre que extrema sus ideas hasta el punto de cambiar el traje de sacerdote por el uniforme de guerrero", y piden al Gobierno de la Nación que indulte de nuevo al Sr. Dueñas ${ }^{35}$. Incluso se hace una suscripción popular abierta por el periódico carlista La Esperanza a favor del cura, en la que se recaudan 2.165 reales $^{36}$.

Desde la cárcel del Saladero (Madrid), pasaría por los calabozos de Escalona y Torrijos. Cuando entró en Torrijos, su pueblo de nacimiento, "fue vitoreado con entusiasmo por muchos de sus parientes y amigos" ${ }^{37}$. En abril de 1873, será conducido de nuevo a la cárcel de Toledo ${ }^{38}$. Tras el juicio correspondiente será trasladado a Madrid junto con "otros 37 presos carlistas de las facciones de Toledo". Pocos días después llegará al puerto de Cádiz, camino de la isla de Cuba, su segundo lugar de destierro. En la isla caribeña sufrirá prisión en La Cañada de la Habana, junto a otros jefes carlistas ${ }^{39}$.

En Cuba permanecerá poco más de un año, pues a mediados de mayo de 1874 "llegaron a Santander procedentes de Cuba 504 carlistas" para ser canjeados por presos liberales. Entre los primeros se encontraba el popular "don Lucio Dueñas, el cura de Alcabón"40, al que se vio que cuando bajaba del barco "llevaba algunas cajas de cigarros habanos para su uso particular" ${ }^{\prime \prime 1}$. Don Lucio será transportado a Madrid. Allí se le otorgará pasaporte para Estella, donde se integraría de nuevo en la filas del aspirante Carlos de Borbón y Austria Este (Carlos VII) ${ }^{42}$.

En Estella se dedicaría a preparar su vuelta a las armas y a reor-

\footnotetext{
${ }^{35}$ El Popular. Diario Independiente. Madrid, 31 de julio de 1872. (En línea. Consulta: 20/01/2020. Disponible en: http://www.memoriademadrid.es/doc_anexos/ Workflow/2/108565/hem_elpopular_18720731.pdf).

${ }^{36}$ La Paz, no 4539. Murcia, 8 de agosto de 1872.

${ }^{37}$ La Correspondencia de España, no 5613. Madrid, 12 de abril de 1873.

${ }^{38}$ La Correspondencia de España, Madrid: no 5384, 24 de agosto de 1872; y 5584,

${ }^{14}$ de marzo de 1873.

El Gobierno, no 105 . Madrid, 5 de abril de 1873.

${ }^{39}$ El Gobierno, no 111 y 119. Madrid, 14 y 23 de abril de 1873.

La Correspondencia de España, no 5879. Madrid, 4 de enero de 1874.

${ }^{40}$ El Estandarte Católico Monárquico. Órgano oficial de los reales ejércitos del Centro y de Cataluña, no 28. Tortosa, 7 de junio de 1874.

${ }^{41}$ El Aviso, no 40. Santander, 20 de mayo de 1874.

${ }^{42}$ El Gobierno, no 1874 . Madrid, 3 de junio de 1874.

${ }^{43}$ El Rompecabezas Carlista. Carlismo y contrarrevolución. (Canal i Morell, 2005, p. 50).
} 


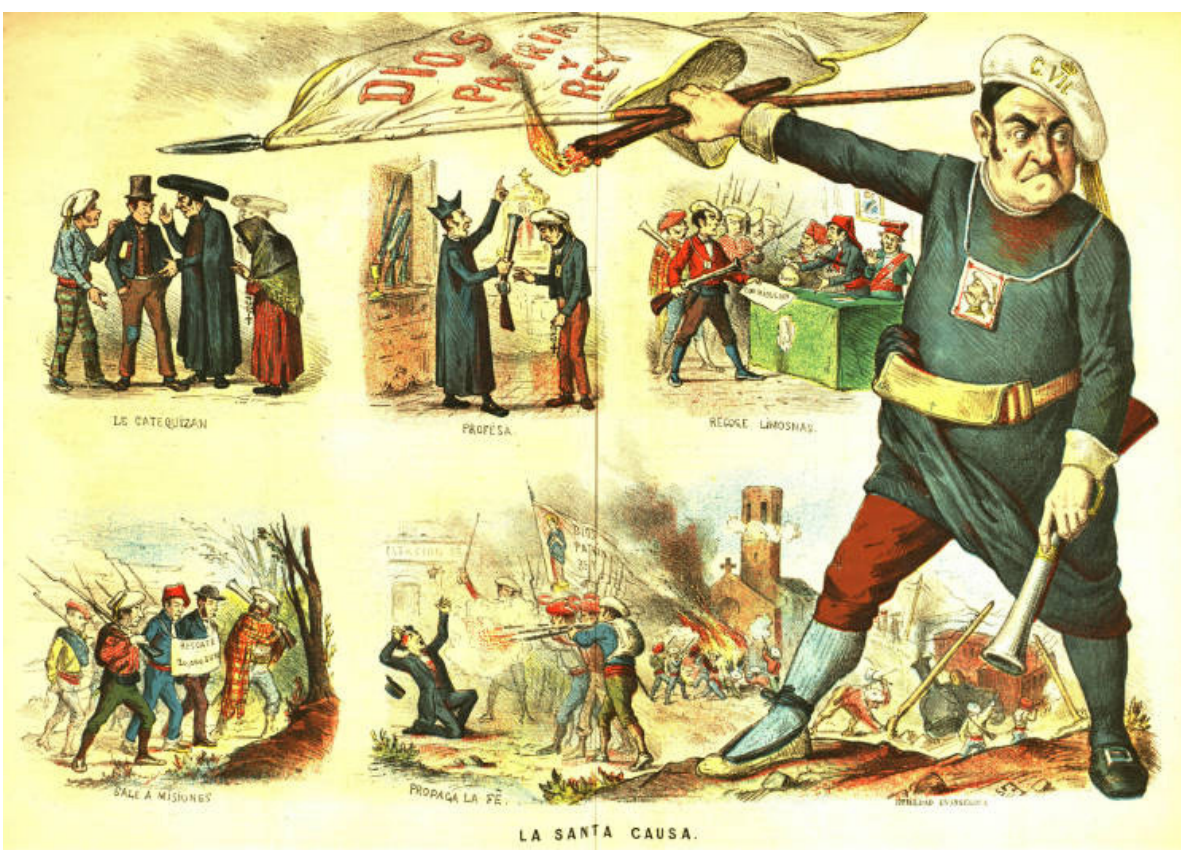

El proceso de reclutamiento y adoctrinamiento de soldados carlistas, satirizado en una secuencia publicada por La Flaca en enero de $1873^{43}$.

ganizar su partida de La Mancha. Seis meses después de su regreso a España, el 26 de diciembre de 1874, el periódico La Correspondencia de Madrid, nos da la señal de alerta: "El cura de Alcabón ha vuelto a sus antiguas correrías convirtiendo a La Mancha en teatro de sus hazañas", ha sido visto en Motilla del Palancar (Cuenca) con una facción de 300 hombres y "se dirige con su partida hacia los Montes de Toledo atravesando la provincia de Albacete" 44 . De nuevo, el ilustre, el resbaladizo don Lucio Dueñas se echaba al monte. Su ideario no había cambiado, a pesar de los años de cárcel y destierro.

\section{LA PROVINCIA DE ALBACETE EN EL ENTORNO DE LA TERCERA GUERRA CARLISTA}

La Tercera Guerra Carlista se deja sentir pronto en la provincia de Albacete. En 1869 "era cortada la línea telegráfica entre Villarrobledo y Chinchilla” por facciones carlistas. En Corral-Rubio y Minaya entran

${ }^{44}$ La Correspondencia de España, no 6233 y 6234. Madrid, 26 y 27 de diciembre de 1874. 
varias partidas carlistas causando robos y saqueos. Durante el reinado de Amadeo I de Saboya (1871-73) se incrementaron las acciones militares de los seguidores del pretendiente Carlos VII, y especialmente se intensificaron a raíz de la proclamación de la Primera República (11 de febrero de 1873). Es durante este año de 1873, cuando numerosos pueblos de la provincia se verán afectados por invasiones carlistas, como Nerpio, Caudete, Letur, Elche de la Sierra, Mahora, Bienservida, Viveros, Hellín, Jorquera, etc. (Asensio, 2011, pp. 231-235).

El 9 de enero de 1874, la propia capital, Albacete, va a ser invadida por la partida de José Santés y Murgui, con 3.000 hombres, causando robos y graves desperfectos ${ }^{45}$. Tomaron la estación de ferrocarril, la Audiencia, e incendiaron el Gobierno Civil. Se hizo una defensa heroica en la torre de la iglesia de San Juan y de la casa cuartel de la Guardia Civil "hasta que fue presa de las llamas". Los carlistas "quemaron los libros del Registro Civil, se apoderaron de unos cuarenta caballos, mil doscientos fusiles [...] y 30.000 duros aproximadamente, de ellos más de 20.000 de la recaudación de contribuciones" (Sánchez, 1916, pp. $46-48,173)$. Tras el ataque sufrido y para evitar nuevas invasiones, se promovieron obras de fortificación de la ciudad construyendo una muralla "de tapial" (Valero, 2015, p. 283) ${ }^{46}$.

Durante 1874, en otros pueblos de la provincia también se dejaron sentir los atropellos de los guerrilleros carlistas: La Roda, Chinchilla, Casas Ibáñez, Villarrobledo, Hoya Gonzalo, Almansa, Hellín, Alcalá del Júcar, Villamalea, Alcaraz, Ossa de Montiel, etc. (Asensio, 2011, pp.231-236). El 3 de diciembre de 1874 será fusilado en "la vereda de Acequión" de Albacete el famoso cabecilla carlista Miguel Lozano Herrero, después de sus correrías por Casas Ibáñez, Alcalá del Júcar, Alatoz, Bonete y Bogarra (Roa, 1894, pp. 88, 202, 213, 215).

\footnotetext{
${ }^{45}$ Ante el temor de que llegasen a Albacete tropas carlistas, el Gobernador Militar, el brigadier don Bernardo Alemany, había constituido la Junta de Defensa y Armamento. Esta Junta estaba compuesta por "don Manuel Reina Falcón, comandante retirado, don Rafael Serrano Alcázar" y otros individuos (Roa Erostarbe, 189194). Don Rafael Serrano Alcázar era el dueño de la finca Navamarín de Lezuza.

${ }^{46}$ Durante la primera guerra carlista también se llevaron a cabo obras de fortificación en la ciudad de Albacete entre 1838-1840 (Valero, 2015, p. 288).
} 


\section{LA MATANZA DE PRADORREDONDO, 27 DE DICIEMBRE DE 1874}

En este ambiente de continuas escaramuzas, persecuciones, y enfrentamientos de las tropas fieles a Carlos VII contra la Guardia Civil y el ejército, el 25 de diciembre de 1874 es detectada una partida de carlistas, bastante numerosa, entre La Roda y Minaya, dirigida por el cura de Alcabón. Alertado el Gobernador Militar de Albacete, envía en su persecución al teniente coronel Portillo, al mando de una columna formada por dos compañías de infantería y 100 soldados de caballería ${ }^{47}$. Tras perseguirlos por Casas de Guijarro (Cuenca), Minaya y Casas de Santa Marta, los carlistas, en su huida, penetraron en el término municipal de Lezuza y llegaron a las Casas de Montoya, "donde el enemigo después de haber descansado allí algunas horas" siguió por Pardales hasta las Ventas de Tiriez ${ }^{48}$.

El día 27 de diciembre, de madrugada, las tropas de Portillo avistaron a los carlistas en Las Ventas de Tiriez. La fuerza que dirigía el cura de Alcabón "se componía de 200 infantes y 40 caballos". El teniente coronel planteó una operación envolvente cortándoles los posibles caminos de escapada y dividió sus fuerzas entre los cuatro puntos cardinales, situando una compañía de infantería "en el camino de la casa de Berruga"; otra compañía en el "camino de la Junquera", y una sección de esta en el camino viejo de Tiriez a Vandelaras (la carretera de Tiriez a Balazote todavía no estaba construida). La caballería, la que dirigía el propio Portillo, se emplazó en el suroeste "en dirección a un espeso bosque", calculando que el enemigo habría de emprender la retirada por allí.

\footnotetext{
${ }^{47}$ El general Manuel Portillo fue un prestigioso y experto militar que había luchado en la Guerra de Cuba durante más de cinco años, dirigiendo al ejército español en la región de Las Villas y El Príncipe. Por discrepancias con su superior (el Capitán General Concha), presentó su dimisión el 17 de abril de 1874, y regresó a la Península (Pirala, 1892, vol. V, 405-408). Ya en España, se incorporó al ejército con el rango de teniente coronel (al reingresar desde Cuba, perdían rango en el escalafón militar).

${ }^{48}$ Narración militar de la guerra carlista (1869-1876), por el Cuerpo Mayor del Ejército, publicada por el Depósito de la Guerra. Tomo XIII. Madrid. Imprenta y Litografía del Depósito de la Guerra. 1889. Págs. 223-228.

(En línea. Consulta: 08/12/2017. Disponible en:

http://archive.org/stream/narracinmilitar07guergoog/narracinmilitar07guergoog_djvu.txt).

Mi agradecimiento a Javier Tejada Ponce, que fue el que me puso en antecedentes de este documento.
} 


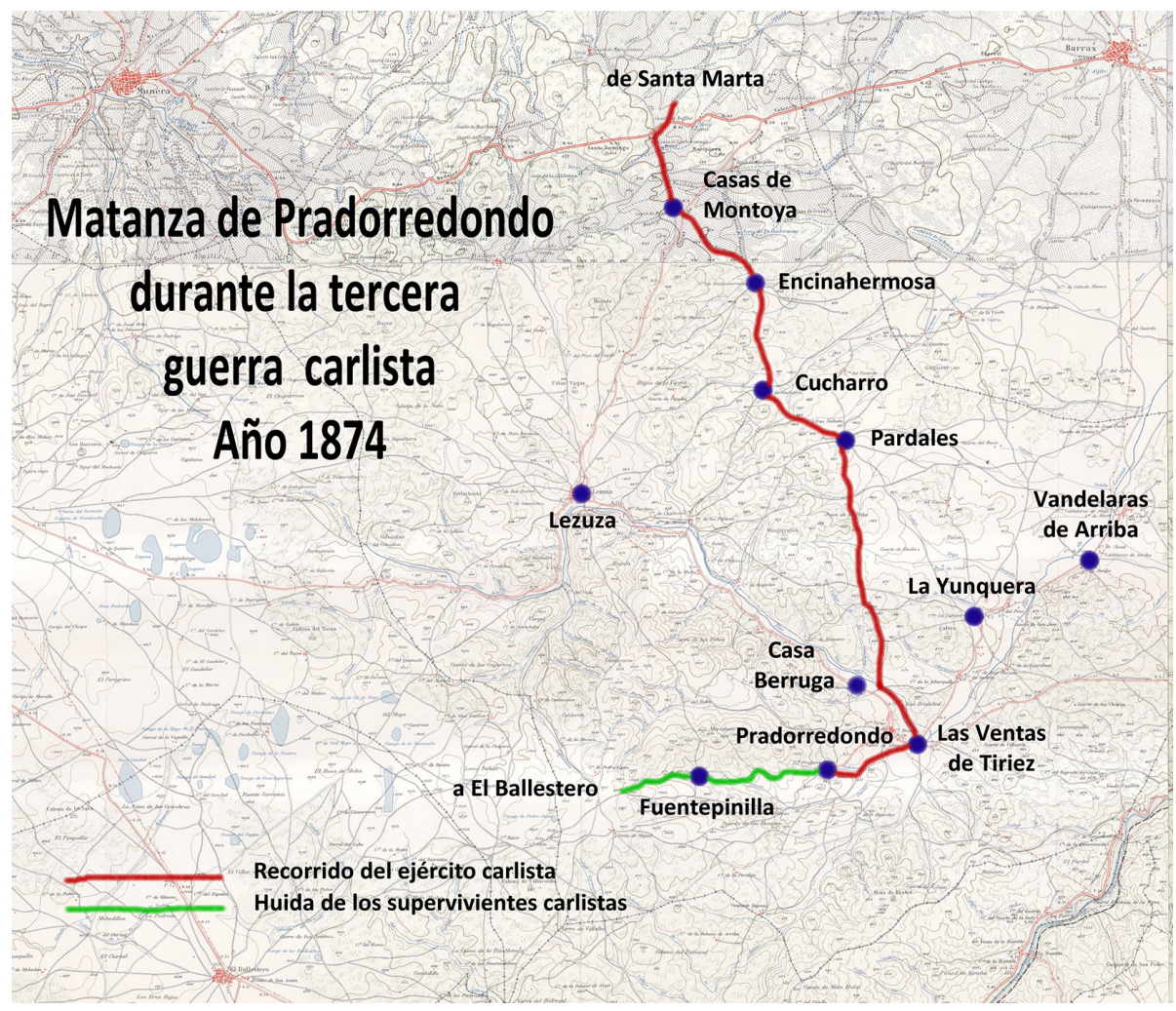

Recorrido de la facción del cura de Alcabón por el municipio de Lezuza. Tras ella, la columna del teniente coronel Portillo. Diciembre de 1874.

(Fuente: Elaboración propia).

Efectivamente, los carlistas huyeron hacia el suroeste, en dirección a Pradorredondo, y se dividieron en tres grupos. La caballería se situó "en el cerro de la choza del Rebullo"49. Al pie de este montículo se colocó la mitad de la infantería, y el resto en el "cerro que se encuentra entre Pradorredondo y Tiriez". El combate empezó a las 7:00 de la mañana, y terminó a las 10:00. Tres horas de fuego intenso y cruzado en un terreno quebrado, con gran masa forestal. Los carlistas fueron acorralados

${ }^{49}$ Actualmente, al lado del camino de los Carros, el que une Las Ventas de Tiriez con Pradorredondo, se encuentra un chozo o cuco al que llaman "cuco de Rebulle", también conocido como "cuco del cerro Pateta". Mi agradecimiento a José Luis Aparicio, Antonio Sánchez Martínez y Amador Jiménez Lapeña, por su colaboración para encontrar "el chozo de Rebulle" y las fosas donde enterraron a los carlistas. El "chozo de Rebullo", al que alude el teniente coronel en el relato de los hechos, es lo que hoy conocemos como "cuco de Rebulle". 


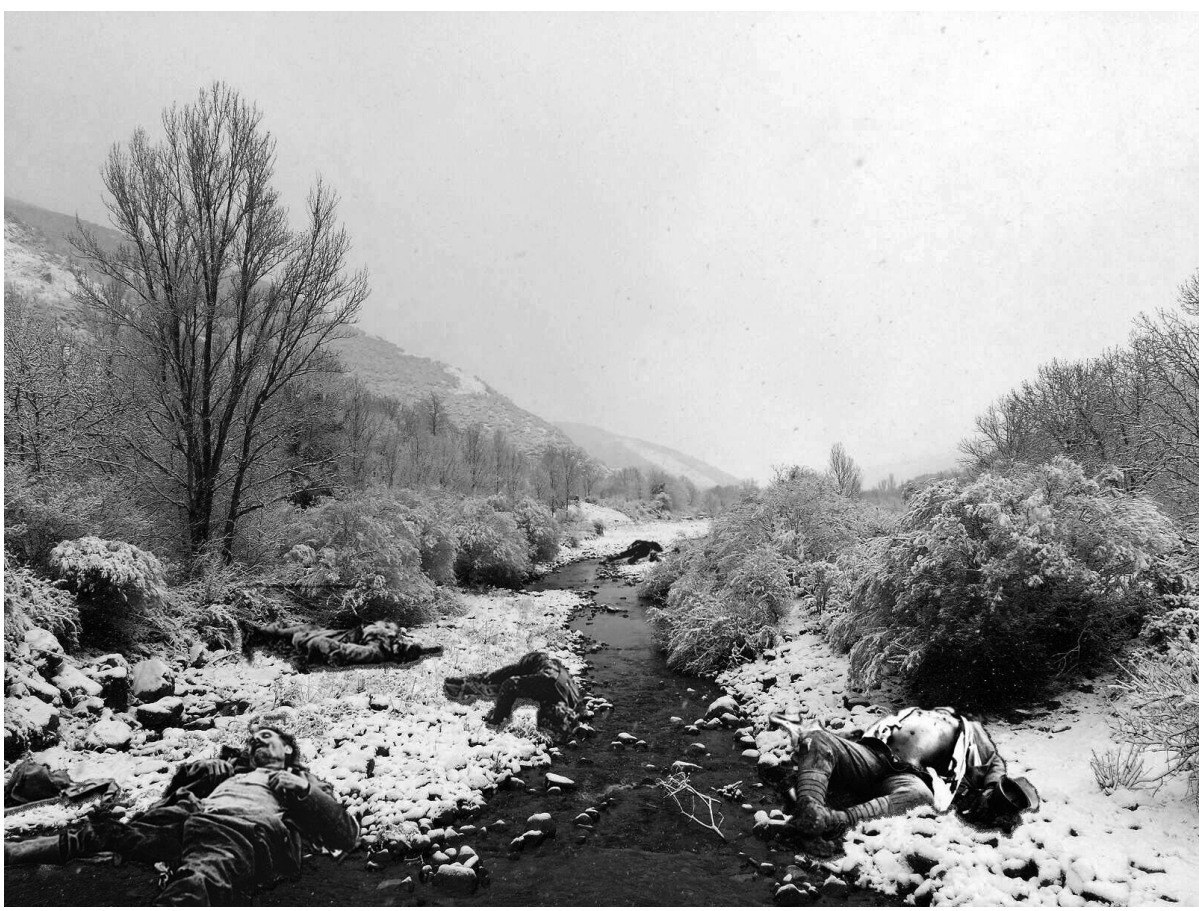

Recreación de la matanza de carlistas junto al arroyo de Pradorredondo. 27 de diciembre de 1874. (por Agustín Fernández Rubio).

y sufrieron, al menos, 114 muertos, "entre ellos un teniente coronel y muchos oficiales". Además, dejaron cuatro prisioneros. Algunos consiguieron escapar "en vergonzosa fuga (...) por el camino de El Ballestero". Las pérdidas hubieran sido mayores "si la nieve que comenzó a caer al principio de la acción y la espesa niebla" no hubieran protegido a los "facciosos" carlistas ${ }^{50}$.

Así lo relata el propio teniente coronel Portillo en una carta fechada el 3 de enero de 1875, carta que remite al Gobernador Militar de Albacete, comunicándole que el "batallón titulado de la Mancha y un escuadrón llamado del Rey [...] mandados por el cura de Alcabón", han sido disueltos en la acción de Pradorredondo, en la que además se han incautado al enemigo "dos cargas de armas, un botiquín, muchas

\footnotetext{
${ }^{50}$ Según el Juzgado de Paz de Lezuza, las tres fosas donde enterraron a los carlistas sumaban 120 muertos. El coronel relata que fueron 114. Es una diferencia inapreciable dada la magnitud de la operación, y se puede explicar por la intensa nevada de aquel día y por la espesura del bosque al que alude el propio documento, lo que haría difícil la localización de algunos cadáveres.
} 
municiones, raciones de pan y pienso". La columna de Portillo solo tuvo "16 heridos, 20 contusos y un caballo muerto", resultado muy ventajoso para la envergadura de la operación. Ni qué decir tiene que Don Lucio Dueñas, fue uno de los que consiguió huir camino de El Ballestero, por la senda de Fuentepinilla. (Ver documento $\mathrm{n}^{\circ}$ 4, donde se transcribe íntegramente el relato del teniente coronel Portillo).

Nos sorprende la gran mortandad ocasionada a la tropa carlista: 114 muertos. Aunque el relato de Portillo reconoce que pudiera ser mayor el número de bajas del enemigo, debido a que muchas no fueron vistas "debido a lo quebrado del terreno, lo dilatado del campo de acción y la copiosa nieve que caía". No conocemos ningún enfrentamiento durante la Tercera Guerra Carlista en Castilla La Mancha que alcanzara unas dimensiones semejantes. También es significativo resaltar que no hubo ningún muerto en el lado gubernamental, tan solo 16 heridos y 20 contusos. No es creíble que en una batalla en campo abierto hubiese semejante desigualdad. Tal vez otros factores, que no desvela el relato del teniente coronel Portillo, influyeran en el resultado de la operación.

La prensa de la época, en Madrid, recogió la noticia: "La derrota de la partida mandada por el célebre don Lucio Dueñas, cura de Alcabón"s1, y dio algunos datos que no recoge el informe del Sr. Portillo. Entre los muertos carlistas figuraba "el Tte. Coronel Pedro Vallejos Peñalver, varios vestidos de oficiales, un médico y dos curas" ${ }^{\prime 52}$.

Un periódico católico-monárquico de ideología carlista, El Iris, publicó el 26 de enero de 1875, un mes después de la tragedia de Pradorredondo, que "el cura de Alcabón fue sorprendido con su partida el mes pasado y dejó en poder del enemigo 108 prisioneros. Estos 108 fueron asesinados en el acto por las fuerzas del coronel Portillo"53. Esta afirmación tajante y acusadora sobre la forma de actuar de las fuerzas guber-

\footnotetext{
${ }^{51}$ El Gobierno, no 903, 904 y 905. Madrid, 28, 29 y 30 de diciembre de 1874. La Correspondencia de España. Madrid, 29 de diciembre de 1874.

${ }^{52}$ Ya hemos comentado anteriormente que en la senda de Fuentepinilla, camino de El Ballestero, a dos kilómetros de Pradorredondo, se encuentra una cruz grabada sobre una gran piedra, a la que los aldeanos llaman "la cruz del cura". Aquí, dicen, que fue encontrado muerto uno de los curas. Según don Juan José Gómez García, cura que fue de Tiriez y de Lezuza, en las obras realizadas en la iglesia de Lezuza en 1991, cuando se limpió la cripta que hay situada debajo de la pila bautismal, se encontraron los restos de dos cadáveres que pertenecían, sin duda, a dos curas, por la vestimenta que llevaban. Es probable, que los dos curas carlistas muertos en Pradorredondo fueran llevados a Lezuza y enterrados en esta iglesia. ${ }^{53}$ El Iris, no 52 . Olot, 26 de enero de 1875.
} 
namentales, aunque venga de una fuente tendenciosa, nos plantea la duda de si el informe de Portillo es veraz en cuanto a la limpieza del combate, o bien, se produjo un fusilamiento masivo de la tropa carlista. Llama poderosamente la atención, tal como hemos señalado anteriormente, que no hubo ningún muerto por el bando de Portillo, tan solo 16 soldados heridos. Esta cuestión trataremos de esclarecerla con el testimonio que nos relatan algunos vecinos de la aldea de Pradorredondo, que se expresa en el punto siguiente.

Debemos aclarar el dato referido al número de muertos en el combate. En la narración de Portillo dice que el enemigo tuvo "unas pérdidas que han consistido en 114 muertos", aunque señala que pudieron ser más. Según el periódico El Iris, fueron 108. En el apartado 4 de este artículo, cuando analizábamos los documentos encontrados en el Juzgado de Paz de Lezuza, expresábamos que los carlistas habían sido enterrados en tres fosas comunes: "el pozo de los 52", "la fosa que contiene los cincuenta y siete" y "la fosa consecutiva de los once". Sumadas las tres fosas, nos dan un total de 120 muertos. La diferencia entre lo que afirma Portillo, El Iris, y lo que escribe el secretario del juzgado, no es significativa. La diferencia mayor alcanza a 12 individuos. La información que publica El Iris correspondería con el testimonio que pudieran ofrecer los supervivientes, y por tanto sería aproximada. La declaración que refiere el teniente coronel está fechada en Cieza (Murcia) el 3 de enero de 1875, siete días después de ocurrir los hechos, por lo que tampoco tendría los datos exactos. Parece más verosímil la información del Juzgado. Por tanto, creemos que la cifra de 120 muertos es la que corresponde fielmente con lo que aconteciós ${ }^{4}$.

\footnotetext{
${ }^{54}$ En el documento que concuerda con el cadáver $n^{\underline{0}} 1$ de los encontrados en el Juzgado de Paz de Lezuza, el que corresponde con Romualdo García Monsalvo, al final aparece: "Acción de Pradorredondo, columna del Teniente Coronel Portillo; facción que acaudillaba el conocido por el cura de Alcabón, don Lucio Dueñas. Murieron 67 carlistas". Este último dato, en un principio, nos indujo a pensar que era el número total de muertos, 67. Posteriormente, los documentos de los cadáveres no 3, 6 y 7, en los que aparecen las referencias a las tres fosas, suman 120 fallecidos. Y por último, el informe de Portillo habla de 114. Esta confusión, a nuestro entender, debe explicarse en que en el documento no 1, "67 carlistas muertos", pudiera corresponder con el primer recuento que se hizo, y dadas las circunstancias adversas de "lo quebrado del terreno [...] con un bosque espeso" unido a la "copiosa nieve que caía" y "la espesa niebla", en ese primer recuento no aparecieron todos los cadáveres. Por tanto, consideramos que la cifra más acertada es la del Juzgado de Paz que asciende a 120 carlistas muertos.
} 
Después de los sucesos de Pradorredondo, no hemos encontrado ningún episodio más de enfrentamiento armado entre carlistas y liberales en la provincia de Albacete

Dos días después de la masacre de Pradorredondo, el 29 de diciembre de 1874, el general Martínez Campos encabezó un pronunciamiento militar en Sagunto que puso fin a la república autoritaria del general Serrano, y proclamó rey de España a Alfonso XII, hijo de Isabel II. Este hecho marcaría el inicio de un nuevo periodo de la historia de España: La Restauración.

\section{LO QUE CUENTAN LOS VECINOS DE PRADORREDONDO Y LA LEYENDA DE LA BOLA}

La aldea de Pradorredondo, en la época que nos ocupa, era una de las más pobladas del municipio de Lezuza. En los datos de población que publica Roa Erostarbe (1891-94, p. 452), Pradorredondo contaba con 125 habitantes, solo superado por La Yunquera, con 166 almas, y Tiriez con $290{ }^{55}$. Cuando ocurren los sucesos de 1874, veinte años atrás, la población de Pradorredondo sería similar a la de Tiriez. A continuación recogemos una copla popular donde se alude a la importancia de estas aldeas (Cruz, 1993, p. 146).

\section{A Pradorredondo lo han hecho villa, y a los Escapes ciudad, y a Fuentepinilla madre, lo van a hacer capital.}

Los trágicos sucesos que acontecieron el 27 de diciembre de 1874 conmocionarían, sin lugar a dudas, a los moradores de Pradorredondo. La brutal masacre que se produjo daría mucho que hablar, en la aldea y en la comarca, durante mucho tiempo. De tal manera que, a día de hoy, los escasos vecinos que allí viven, o los de Tiriez que tienen sus raíces en esta aldea, todavía cuentan las historias que sus antepasados les transmitieron.

Las diversas fuentes consultadas, especialmente Agustín Parreño González, entrevistado por El Cirio Cascarrín en 1992, cuando contaba con 70 años; y José Bañol Sánchez, entrevistado en julio de 2017, con 80 años; ambos nacidos y criados en Pradorredondo, narran la muerte de los carlistas como una matanza que se produjo dentro de la aldea. Decía

${ }^{55}$ La población total del municipio era de 3.149 habitantes, de los cuales residían en Lezuza 1.671. Años 1891-1894. 
Agustín que "mis padres me contaron que los carlistas llegaron a Pradorredondo huyendo, y se escondieron en habitaciones [...], en mi casa metieron cinco y los taparon con paja, otros los metían en hornos". Continuaba afirmando que "en mi casa mataron a los cinco, a otros los mataron en la placeta"s6.

José Bañol nos contaba que "la aldea la acorralaron las tropas, los que iban huyendo se metían donde podían, en las habitaciones, en las arcas, en los corrales, en las cuadras, en la cueva, en el horno [...] la gente de la aldea los protegía". Decía José que en la casa de Jesús Purita, muchos se escondieron en el horno, y allí también se refugió una mujer que iba con los carlistas, a la que los vecinos le dieron un bebé para que lo tomara en brazos, y así pasó desapercibida entre los soldados. Asegura José que "a la mayoría los mataron en la placeta", y a los otros donde se los fueron encontrando, en los corrales, en el pajar, en el horno, ...

José relata que en una casa que había al lado de la suya, "se ampararon tres carlistas" y se metieron en un arca. El zagal de la casa los delató a los soldados. Estos entraron en la casa con los fusiles, los sacaron a la placeta "y les dieron un tiro en la cabeza". El zagal, a los pocos días, fue a labrar con las mulas, llevaba un capote con capucha porque estaba lloviznando, por el camino dejó de lloviznar y echó el capote en el lomo de la mula, esta le dio una coz y lo mató. En la aldea se dijo que aquella muerte fue en venganza por haber denunciado a los carlistas. La emoción de José Bañol se refleja en el rostro contando estos detalles, como si los hubiese vivido en primera persona.

Agustín hablaba de la muerte de dos curas, y José afirma que mataron a un cura en el camino de Fuentepinilla. Según hemos expresado anteriormente, a dos kilómetros de Pradorredondo, en el camino que va a Fuentepinilla y a El Ballestero, se encuentra "la cruz del cura". Según los aldeanos, Francisco Perrilla el Viejo, que entonces tendría 15 o 16 años, cuando bajaba desde Fuentepinilla a Tiriez a "abuzar las rejas" se encontró a un cura muerto ${ }^{57}$. Coincide fielmente con lo referido del cadáver no 2: "un sacerdote, como de 36 a 40 años, [...] se halló cadáver en la senda de Fuentepinilla".

\footnotetext{
${ }^{56}$ El periódico escolar, El Cirio Cascarrín, del colegio público Virgen de la Cruz de Lezuza, publicó, en marzo de 1992 y abril de 1993, entrevistas y artículos relacionados con los sucesos acaecidos en Pradorredondo en 1874. Las entrevistas y artículos fueron realizados por alumnos del Centro dirigidos por el que suscribe. ${ }^{57}$ Abuzar las rejas: Abuzar o aguzar las rejas, quiere decir afilar, adelgazar las rejas de los arados o vertederas.
} 
La versión que dan los vecinos es, en una parte, más verosímil que la que hace el propio teniente coronel Portillo. El militar hace una narración de los hechos dirigida a su superior, donde trata de magnificar la acción: "todos se excedieron a sí mismos (...) por su valor indomable frente al enemigo", destacando la heroicidad de sus oficiales, con el fin de obtener un ascenso. Portillo relata una batalla en campo abierto, y no dice nada de la muerte de soldados carlistas dentro de la aldea.

Según hemos manifestado anteriormente, de los ocho documentos encontrados en el Juzgado de Paz, el que corresponde con el cadáver $\mathrm{n}$ - 4, dice textualmente el escribano que "según manifestación de un aldeano aquel era natural de Alcázar de San Juan y estaba casado". Del cadáver no 6 se escribe que "era hijo de Juan y Dorotea, antecedentes que antes de morir facilitó a los aldeanos". Estos detalles evidencian que los vecinos tuvieron relación con los carlistas, y que muchas de las muertes se produjeron dentro de la aldea. Lo anterior no quiere decir que no hubiera muertes en el campo de batalla, entre Tiriez y Pradorredondo, que sin duda las hubo.

Las circunstancias que aportan los documentos del Juzgado de Paz de Lezuza, más la información contrastada de los vecinos de Pradorredondo, confirmada por otras fuentes orales de Tiriez y Lezuza, corroboran en parte la publicación del periódico El Iris. De lo que deducimos que muchos carlistas fueron asesinados, o fusilados, o masacrados por la tropa del teniente coronel Portillo.

Los documentos del Juzgado hablan de tres fosas en las que se enterraron los cuerpos de los 120 carlistas. José Bañol nos señala dos lugares de enterramiento. Uno, en la cañada de los almendros, a 200 metros de la aldea. Aquí, deducimos, enterraron a 57 cadáveres. El otro, "en la cuesta del pino", a unos 400 metros, junto a la carretera que conduce a Tiriez, cerca del chozo de Rebulle, en el cerro Pateta. Recordemos que "la choza del Rebullo" es citada por Portillo en su informe al Gobernador Militar de Albacete. En este sitio se encuentra la fosa de los 52 y "la consecutiva de los once". También refiere José, que cuando llegaba el día de Todos los Santos, las mujeres de la aldea "llevaban luces" (velas encendidas) a las sepulturas donde fueron enterrados los carlistas.

Pero sin duda, lo que más ha trascendido de aquellos hechos a las generaciones posteriores, fue lo que El Cirio Cascarrín llamó "La leyenda de la Bola". La Bola, o la tía Bola, se llamaba Águeda. Estaba casada en primeras nupcias con un tal Severiano de Balazote. Al morir este, 


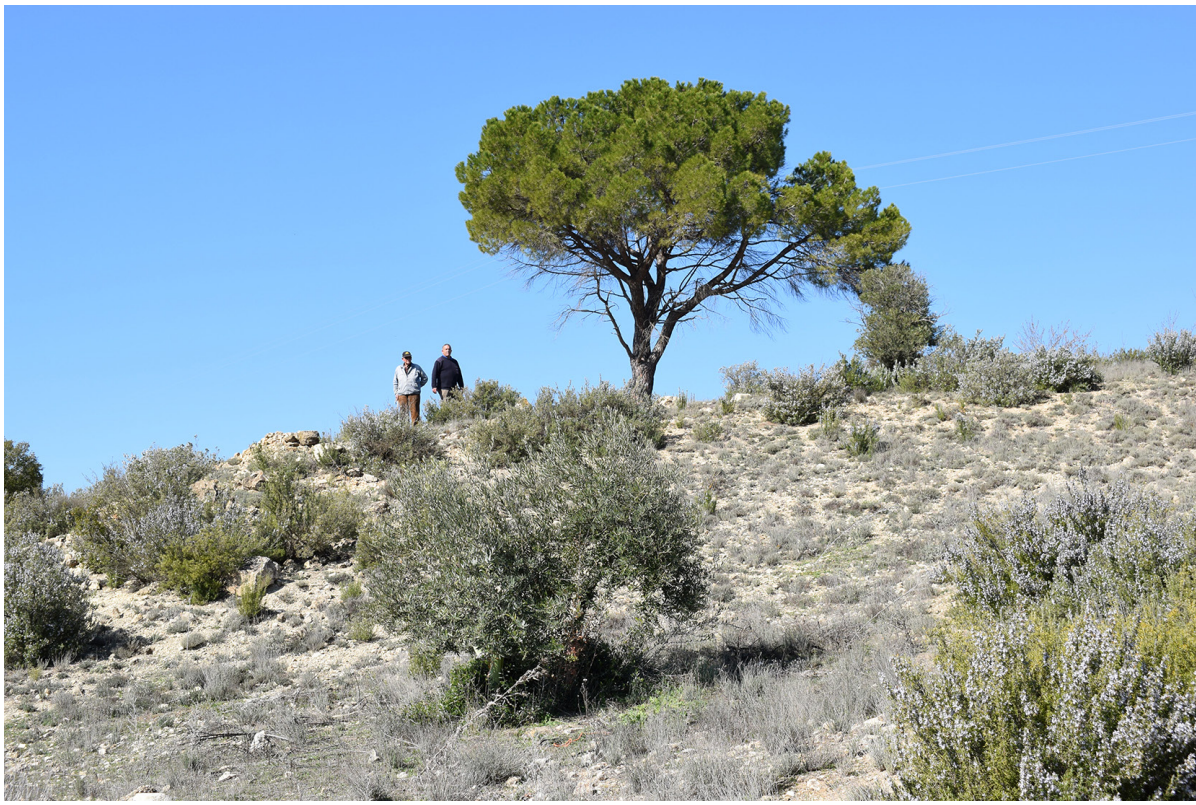

"La cuesta del Pino", a 400 metros de Pradorredondo. Uno de los lugares donde se encuentran dos fosas comunes en las que enterraron a los carlistas.

(Foto: J. A. Munera).

contrajo matrimonio con Pablo, de La Herrera, al que llamaban "El tío Azul". La Bola era una de las mujeres más dispuestas y "echás p'alante" de la aldea. Ella se encargaba de organizar las fiestas, los carnavales, y proponer soluciones a los problemas que se pudieran plantear.

Cuentan que, cuando llegaron los carlistas huyendo de las tropas del Gobierno, La Bola vio desde "el ventanillo" de su casa que iba una mula sola cargada con unos sacos en las alforjas. La Bola pasó la mula al corral de su casa, descargó los sacos y los escondió. Según los vecinos, los sacos estaban llenos de oro y dinero que llevaban los carlistas ${ }^{58}$.

El Tío Azul le daba mala vida a La Bola, le pegaba, y la amenazaba con matarla si no le decía donde estaba el oro que tenía escondido. En una ocasión, un vecino de la aldea fue a pedirle dinero, pues ella "manejaba cuartos", y dicen que la vieron subir a la cámara y revolver entre el

\footnotetext{
${ }^{58}$ Eran corrientes los robos y secuestros que cometían las partidas carlistas y que dieron lugar a historias sobre "los tesoros de los carlistas", con más o menos fundamento. Según hemos señalado anteriormente, cerca de aquí, en Munera, en la aldea de la Bediguilla, en 1837, los carlistas "se llevarían como rehén a una mujer y a sus dos hijos, por cuyo rescate pedían la cantidad de unos 15.000 reales". (Asensio, 2011, p. 212).
} 


\section{FOSAS COMUNES DE LOS CARLISTAS}

\section{7 de diciembre de 1874}

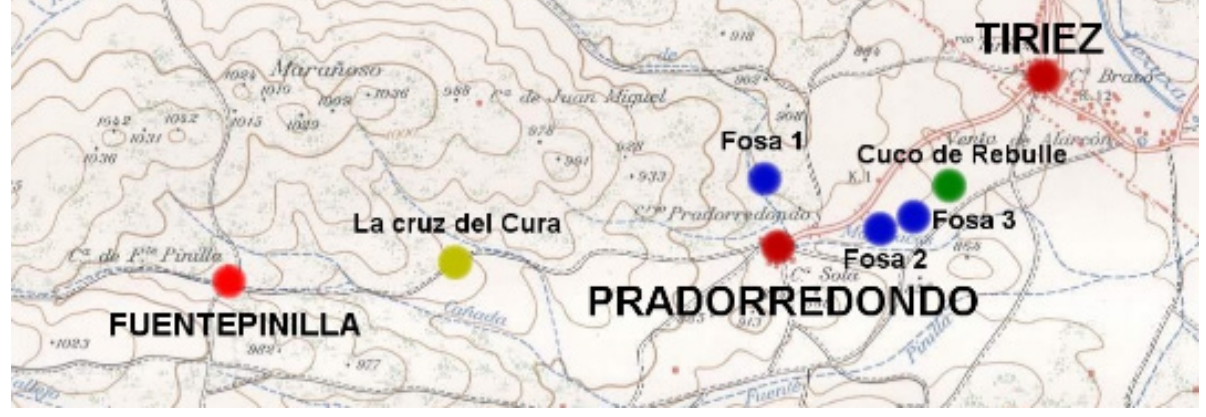

Lugar de enterramiento de los 120 carlistas. Fosa 1: 52 soldados; Fosa 2: 57 soldados y Fosa 3: 11soldados. (Fuente: Elaboración propia).

trigo. Cuando La Bola volvió de un viaje que hizo a Albacete, le habían robado el oro.

En otra ocasión, la tía Bola y el tío Azul fueron a la feria de Albacete, por el camino viejo, y a la altura del monte de los Monegrillos, al pasar La Herrera, el tío Azul, en un arrebato, "la mató con una horca de hierro" y después la colgó de un árbol. Algunos dicen que fue su sino, pues había delatado a unos carlistas que estaban escondidos en el horno de Jesús Purita, que después fueron fusilados.

Historias y leyendas sobre tesoros arrebatados a los carlistas, como esta de La Bola, no es difícil encontrar en los pueblos de la provincia. La fundamentación real queda demostrada en este artículo. Las partidas carlistas se dedicaban al saqueo, robo, secuestro y todo tipo de extorsión por donde pasaban. En la comarca, además de la leyenda de Pradorredondo, encontramos dos ejemplos de ello.

En Barrax, el 3 de agosto de 1861 fueron asesinadas doña Ana Francisca Soto y su moza, Ana López. Doña Ana Francisca era viuda de don Pedro, un labrador rico de Barrax. Los asesinos, Esteban López, Joaquín Simarro y Alonso Cano, moradores de la misma villa, se conjuraron para robar el oro y las riquezas que la viuda escondía en su casa. Según decían en el pueblo ascendían a 40.000 reales $^{59}$. Esta grandísima

\footnotetext{
${ }^{59}$ La Correspondencia de España. Diario Universal de Noticias, no 1421 . Madrid, 7
} 


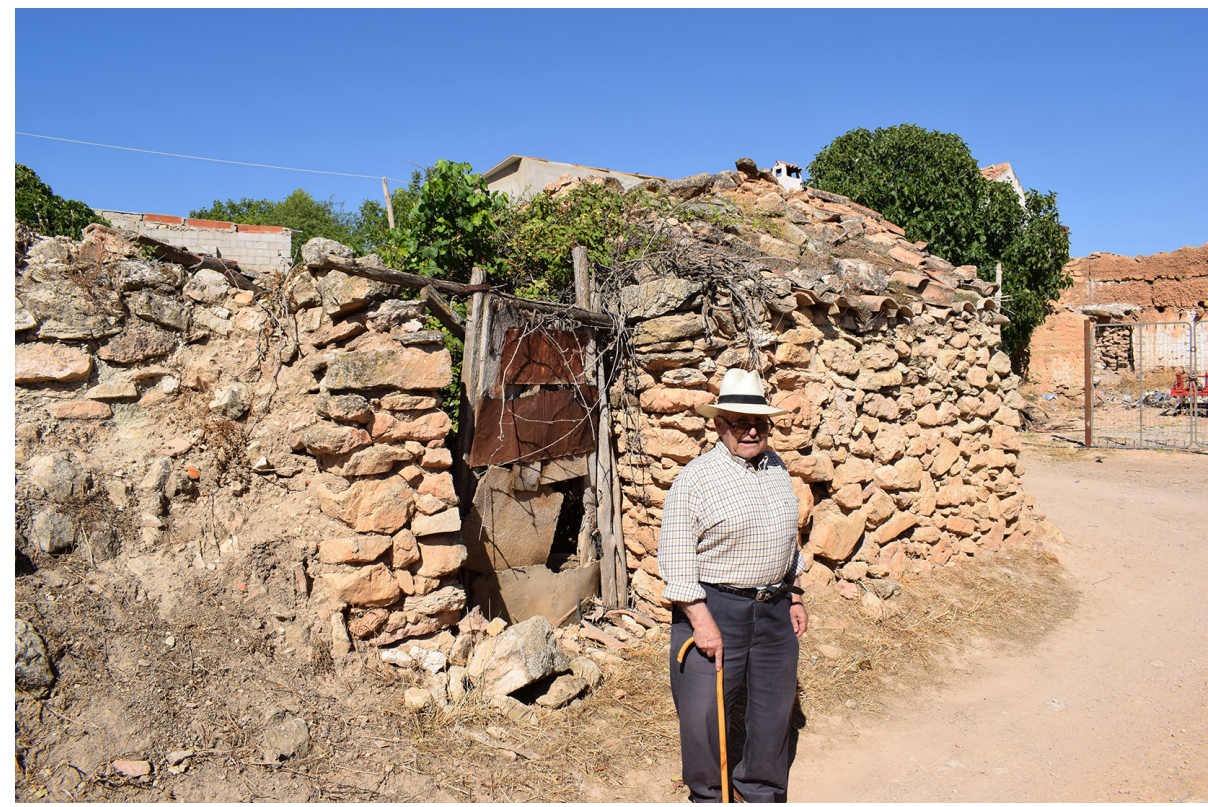

José Bañol junto a la casa de Jesús Purita, en Pradorredondo, donde mataron a unos carlistas que estaban escondidos en el horno. (Foto: J. A. Munera).

suma provenía del dinero que le quitaron a la partida de carlistas, que dirigida por el coronel Tallada, fue apresada en la aldea barrajeña de San Gerónimo en 1838 (ver punto 3 de este artículo). Pedro, el marido de doña Ana Francisca, era hermano de uno de los participantes en la captura de Tallada y su facción. Las habladurías del pueblo daban por seguro que la viuda guardaba celosamente en su casa los tesoros que les aprehendieron a los carlistas. Los asesinos serían juzgados y condenados a la pena capital ${ }^{60}$. Fueron ejecutados "por garrote vil" en la plaza de Barrax el día 2 de octubre de 1862 (Sánchez, 2013, pp. 120-128).

Otra leyenda de tesoros y de carlistas la encontramos en la vecina localidad de El Ballestero. Cuenta Valero (1993, pp. 35-36), que una partida de carlistas llegó a la casa de Juan Tomás de Frías y del Castillo, rico terrateniente de Torre de Juan Abad (Ciudad Real). Una vez allí, robaron cuanto

de mayo de 1862.

(En línea. Consulta: 02/02/2020. Disponible en:

https://prensahistorica.mcu.es/es/consulta/resultados_ocr.do).

${ }^{60}$ Alonso Cano, uno de los reos, en el momento de la ejecución, cuando subió al patíbulo mostró "una estampa de la Virgen de la Cruz", e imploró su auxilio. (Sánchez, 2013, p. 127). Este dato nos lleva a afirmar que el reo tenía sus orígenes familiares en la vecina localidad de Lezuza, donde esta imagen es la patrona de la villa. 
pudieron, "cargaron varias mulas para llevarse consigo todas las joyas, dinero y cosas de valor" que encontraron en la casa. En la huida caminaron por sendas poco transitadas y desconocidas para ellos, y se perdieron. En la oscuridad de la noche, una de las mulas, que era también robada, se alejó y volvió a su lugar de origen, que no era otro que la pequeña población de El Ballestero. La familia, a la que le robaron la mula, se encontró que en sus alforjas iba "la mítica clueca de oro con sus polluelos".

Estos últimos relatos, junto con la Leyenda de la Bola, nos vienen a confirmar, que hechos históricos que acontecen en los pueblos, son conservados en la memoria colectiva de sus gentes, y aunque modificados, dramatizados, ensalzados o idealizados, llegan hasta nosotros, transmitidos de generación en generación.

\section{EL FINAL DEL CURA DE ALCABÓN}

¿Y qué pasó con el famoso cura de Alcabón? Dijimos que consiguió salir con vida de la masacre de Pradorredondo. Dos sacerdotes, compañeros suyos, no tuvieron la misma suerte, perdieron la vida en manos de las tropas del teniente coronel Portillo.

\subsection{Es apresado cerca de la Venta de Borondo (Daimiel) y vuelve a la prisión en Menorca}

Los supervivientes de la partida de don Lucio Dueñas huyeron por el camino de Fuentepinilla, y desde aquí hacia El Ballestero. Buscarían un lugar seguro para esconderse del ejército y de la Guardia Civil. Ese lugar no podía ser otro que el que mejor conocían, las sierras del norte de la provincia de Toledo. Pero para ello debían cruzar toda la provincia de Ciudad Real.

El 31 de diciembre de 1874, cuatro días después de los sucesos de Pradorredondo, fue advertida "una partida de facciosos" en el término de Valdepeñas, que galopaba en dirección a Almagro. Se comunicó, por telegrama, tal movimiento a las autoridades del ayuntamiento de esta última localidad para apercibirlas. Inmediatamente se puso en marcha tras su pista el capitán don Manuel Lambea, al frente de 45 carabineros. El día 1 de enero de 1875 fue localizada la partida en la Casa del Pardillo, cerca de la Venta de Borondo, en el término municipal de Daimiel. A la cinco de la mañana, el capitán Sr. Lambea, cercó la aldea y "dispuso el ataque sin demora penetrando en el patio a la bayoneta con 
la mayor bravura". Los carlistas fueron sorprendidos, "pidieron cuartel" y entregaron las armas. Entre los 16 facciosos apresados se encontraba el cura de Alcabón, que "causó una impresión penosa por su carácter de sacerdote que tan mal se aviene con sus actos". Entre los capturados estaban, además del cura, dos tenientes coroneles, un comandante, un capitán, un teniente, cinco alféreces, un oficial de administración militar, un cabo primero, un corneta y dos soldados. Todos los prisioneros fueron conducidos a la cárcel de Ciudad Real. Desde aquí, el 11 de enero, don Lucio Dueñas y el resto de su partida fueron escoltados por los carabineros, en "el tren de Andalucía", hasta Madrid ${ }^{61}$.

Volvemos a saber de don Lucio el 22 de mayo de 1875, cuando llegaron al puerto de Alicante 145 presos carlistas, "entre ellos el célebre cura de Alcabón que cubría la cabeza con una boina de lana blanca con borla de oro, vestía pantalón grande con franja azul y bota de montar". Estaba claro que era el centro de atención allá donde iba, no solo para la prensa, sino también para el pueblo llano, que veía al cura "con faz serena y atrevida mirada" " "recibía sin inmutarse las curiosas miradas de la multitud que llenaba el muelle". Junto al cura de Alcabón iban otros señalados oficiales carlistas, como su compañero de guerrilla Félix Alonso Quirós Mulita, los comandantes Maldonado y Barreda y 15 oficiales más ${ }^{62}$.

Desde Alicante embarcarán en el vapor Correo de Alicante con destino a Menorca, donde serán recluidos en la prisión-fortaleza Isabel II, también conocida como La Mola (prisión que ya conocía el Sr. Dueñas, pues estuvo recluido en ella en 1870 durante tres meses, antes de su primer destierro, a Francia). En este presidio se encontraban más de dos mil prisioneros carlistas, "toda clase de tropa, harapientos y sin uniformar, viejos muchos y niños no pocos, con boina los menos [...] los más fueron encerrados en los barracones de los cuarteles alto y bajo de la fortaleza, cuarteles convertidos en depósitos". Así lo cuenta uno de los vigilantes de la prisión, que conocía al célebre cura de Alcabón ${ }^{63}$.

El 19 de septiembre de 1875 conocemos, a través del diario El

${ }^{61}$ La Correspondencia Española, no 6240, 6241 y 6250. Madrid, 2, 3 y 12 de enero de 1875.

El Bien Público, no 561. Mahón, 12 de enero de 1875.

${ }^{62}$ La Correspondencia de España, no 6381. Madrid, 22 de mayo de 1875.

El Constitucional, diario liberal, no 2142. Alicante, 25 de mayo de 1875.

${ }^{63}$ El Bien Público, no 8534. Mahón, 30 de agosto de 1901.

Lo narra en el periódico uno de los vigilantes de la Mola, don Juan Lapoulide. 
Bien Público de Mahón, que desde la fortaleza Isabel II "60 carlistas han sido trasladados a las prisiones que existen en el Hospital Militar de este plaza, entre los cuales vimos algunos jefes y al cura de Alcabón"64. Este traslado se explica, probablemente, porque tendrían un trato de favor algunos de los oficiales más destacados.

Con la llegada de Alfonso XII a Madrid, en enero de 1875, se restauró la monarquía borbónica y el carlismo fue perdiendo fuerza, hasta caer la última plaza, la ciudad de Estella (Navarra). Carlos VII cruzó la frontera en febrero de 1876, y pronunció aquellas míticas palabras: “¡Volveré!”. La Tercera Guerra Carlista había terminado.

Alfonso XII facilitó un nuevo indulto en febrero de 1876 (Arnabat, 2018), al que se acogió nuevamente nuestro cura guerrillero, tan solo debía jurar lealtad al rey y a la constitución, cosa a la que ya estaba acostumbrado. El día 10 de junio de 1876 llegaba de nuevo a Madrid "procedente de Alicante, el famoso cura de Alcabón"65.

\subsection{La repercusión en la prensa tras el indulto de $\mathbf{1 8 7 6}$}

Tras la finalización de la tercera guerra, unos 20.000 carlistas cruzaron los Pirineos y se refugiaron en Francia. Muchos de ellos regresarían a España acogiéndose a los indultos promovidos por el Gobierno de Alfonso XII (Aróstegui, 2003, 87-88). Tal como hemos señalado anteriormente, don Lucio, desde la prisión de La Mola, en Menorca, volvería a la diócesis de Toledo y se incorporaría a ejercer su oficio de sacerdote en su parroquia, y como decía Benito Pérez Galdós (2005, p. 5455), "sin que nadie le molestara continuaría ejerciendo su ministerio espiritual, elevando la Hostia con sus manos sacrílegas". Sin embargo, no pasaría desapercibido para la prensa española, pues continuamente se hace referencia a su persona y a su actividad durante la última guerra civil.

Su osadía, altivez y falta de arrepentimiento le llevaron a dirigirse el 28 de diciembre de 1879 al Presidente del Congreso de los Diputados para que se le concediese "la cruz laureada de San Fernando",

${ }^{64}$ El Bien Público, no 767. Mahón, 19 de septiembre de 1875.

${ }^{65}$ Diario Oficial de Avisos, no 162 . Madrid, 10 de junio de 1872.

${ }^{66}$ La Mola. Fortaleza Isabel II. Mahón Menorca.

(En línea. Consulta: 08/04/2020. Disponible en:

https://upload.wikimedia.org/wikipedia/commons/a/a8/Fortalesa_de_La_Mola_\%28Menorca\%2C_2_de_agosto_de_2014\%29_35.JPG) 


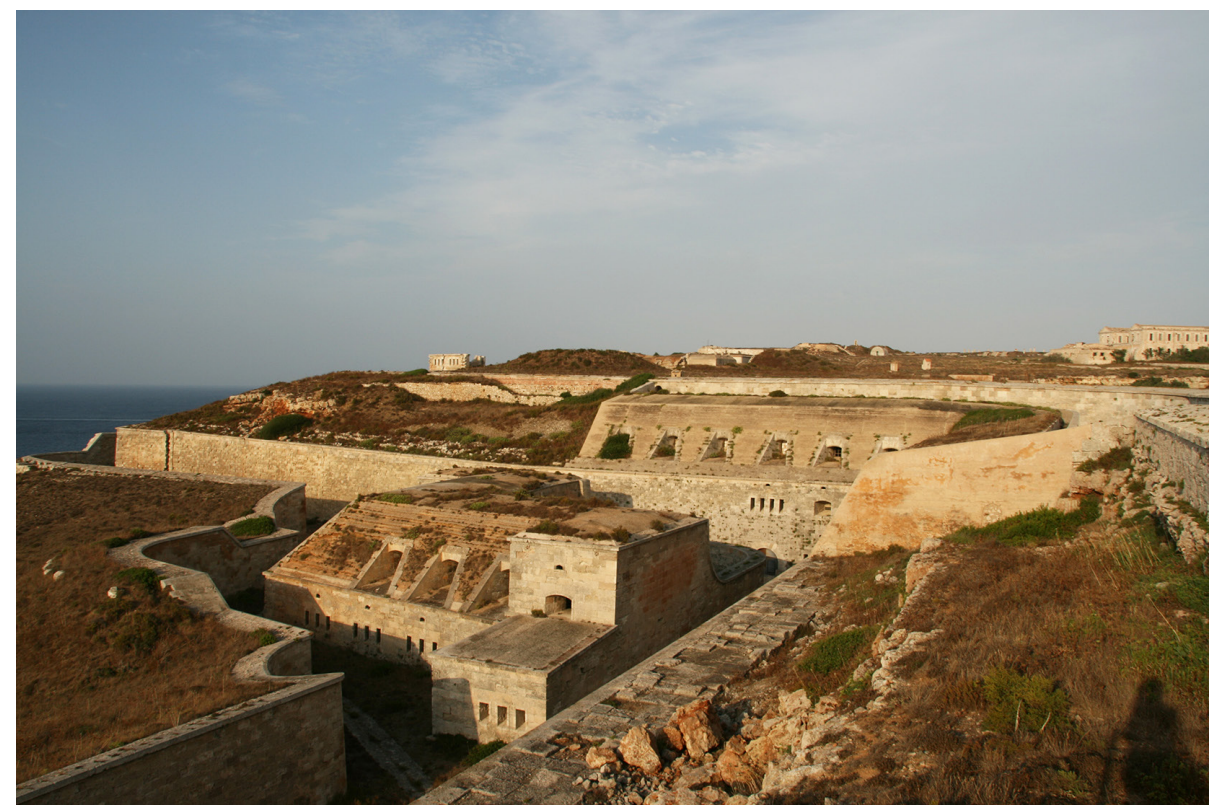

Fortaleza Isabel II, también conocida como La Mola, Mahón (Menorca). El cura de Alcabón estuvo preso aquí en dos ocasiones: En 1870 y 1875-1876 ${ }^{66}$.

la más alta condecoración militar del reino. Don Lucio acompañó su solicitud con una documentación que pasó a la comisión correspondiente ${ }^{67}$. Por supuesto, no consta su concesión.

Era frecuente en la prensa liberal de la Restauración hacer revisión del reciente pasado guerracivilista, y en especial del papel que jugó una parte importante del clero español ${ }^{68}$. Encontramos citas continuas al cura de Santa Cruz (Manuel Ignacio Santa Cruz, que actuó en el País Vasco y Navarra); al cura de Flix, diócesis de Tarragona (José Agramunt, coronel del ejército carlista); a mosén Pacho (capellán en la división de Aragón); al Obispo Caixal (José Caixal, obispo de Urgel); y sobre todo al "celebérrimo cura de Alcabón".

${ }^{67}$ El Comercio, diario de Valencia, no 812. Valencia, 28 de diciembre de 1879.

${ }^{68}$ Manuela Asensio (2011, pp. 56, 279) destaca en Castilla la Mancha la participación de los siguientes curas guerrilleros en la primera guerra: el cura Quintanilla, el cura Solera, el cura de Peñalén, el cura de Caltojar, el capellán de Burlaguena, etc. En la tercera, además del cura de Alcabón, cita al canónigo Manterola y a Antolín Monescillo.

Mª Pilar Córcoles (Córcoles, 1999, pp. 170-171) cita a varios sacerdotes de Albacete vinculados con los carlistas en la primera guerra: Juan Sánchez, Gervasio Martínez y José García. 
Nos encontramos comentarios muy duros en los periódicos referidos a los sacerdotes anteriores. Sirva como ejemplo los que aparecen a continuación, como que "convirtieron durante la guerra civil muchos templos en depósitos de armas y en centros permanentes de conspiración" ${ }^{\prime \prime}$, o que de los seminarios "salieron multitud de jóvenes levitas para defender nuestra santa religión a trabucazo limpio"70. 0 este otro publicado por El Ideal de Gerona: "numerosos curas que fueron el terror de las comarcas en que llevaban a cabo sus fechorías ${ }^{\prime 11}$. El anticlericalismo que se percibía en una parte de la sociedad española se reflejaba en la prensa.

Ante la división que existía en el partido Carlista bajo la dirección de don Cándido Nocedal, líder de los "neocatólicos", que defendían la actuación del carlismo dentro de la legalidad; había otros, que querían de nuevo la sublevación militar (Tusell, 1996, p.134). Dentro de estos últimos estaban históricos guerrilleros carlistas como Pascual Cucala, el cura de Flix y por supuesto, el cura de Alcabón $n^{72}$, que contaban con el apoyo de periódicos afines al carlismo como La Fe y El Cabecilla. Precisamente a estos medios mandó don Lucio una carta en septiembre de 1882 donde arremetía contra los dirigentes del partido: "guerra a los farsantes" escribía, a los que acusaba de ser poco beligerantes con la causa, y recordaba que en sus tiempos sufrían por ella "hambre, sed y balas". Añadía, que "a los verdaderos carlistas no se nos cansa la mano" de empuñar las armas por defender "nuestra santa causa: Dios, Patria y $R e y^{\prime \prime 3}$. Don Lucio Dueñas cumplía años, pero seguía terco y obstinado en su defensa a ultranza de su ideario carlista tradicionalista y ultracatólico, a pesar de los mil y un contratiempos, derrotas, cárceles y destierros que tuvo a lo largo de su vida.

La popularidad del cura de Alcabón llegaba, no solo a los perió-

\footnotetext{
${ }^{69}$ Crónica Meridional. Diario liberal independiente, no 6238. Almería, 28 de noviembre de 1880 .

${ }^{70}$ La Opinión, no 1077 . Palma de Mallorca, 16 de julio de 1883. (Artículo firmado por Eladio Lezama).

${ }^{71}$ El Ideal, periódico republicano, no 99. Gerona, 16 de abril de 1905.

${ }^{72}$ El Diario de Murcia, no 1801 . Murcia, 19 de septiembre de 1882. La Opinión, no 890. Palma de Mallorca, 20 de septiembre de 1882.

El Liberal: órgano democrático de la isla de Menorca, nº 374. Mahón, 25 de septiembre de 1882.

${ }^{73}$ El Diario de Lugo, no 1777 . Lugo, 13 de septiembre de 1882.

El Graduador, no 3161. Alicante, 16 de septiembre de 1882.
} 
dicos de la capital del reino, se hacía extensiva a todas las provincias, incluso hasta en La Habana (Cuba) ${ }^{74}$. En Santander, en 1882, La Voz Montañesa le dedica estos versos:

El reverendo cura de Alcabón, que lleno de bondad y dulzura por defender al héroe del Toisón, dejó, como buen cura, el misal, el hisopo y el copón, y armado de trabuco y de canana se fue a la guerra insana, dispuesto a recorrer campos extensos con la misión cristiana de matar liberales indefensos (continúa) ${ }^{75}$.

Don Lucio Dueñas, murió en Torrijos, su pueblo natal, el día 7 de noviembre de 1901, a la edad de 84 años $^{76}$, después de haber pasado por innumerables cárceles, beneficiarse de una amnistía y dos indultos, haber sido canjeado otra vez por prisioneros liberales, y tras padecer dos destierros. Según Pirala (1892, vol. II, p. 582), tan arraigadas tenía sus ideas carlistas, que mereciendo una recompensa por los servicios que prestó en la epidemia de cólera de 1855, no quiso admitirla "por no querer nada de ningún gobierno liberal". Todo un personaje. Un referente en la historia del carlismo español.

Su memoria continuó después de su muerte. Seguimos encontrándonos con acusaciones muy fuertes hacia su persona, tratándolo de asesino. Por ejemplo, en 1903 en El Pueblo de Tortosa: "En esta guerra pasada, los curas de Alcabón, el de Flix y el de Santa Cruz, horripila solo el pensar los crímenes que cometieron"78. 0 El Radical de Almería en 1908: "aquellos días en que los curas de Alcabón y Santa Cruz asesinaban liberales en nombre de Dios, de la Patria y del Rey"79. Cierto es que el cura Santa Cruz se distinguió

\footnotetext{
${ }^{74}$ Diario de la Marina, $\mathrm{n}^{\mathrm{o}}$ 114. La Habana (Cuba), 14 de mayo de 1935. Se hace mención del cura de Alcabón en un artículo sobre Bernardo Moraleda, "el último bandido de los Montes de Toledo".

${ }^{75}$ La Voz Montañesa, no 2319 . Santander, 15 de septiembre de 1882.

${ }^{76}$ La Atalaya, diario de la mañana, no 3164. Santander, 9 de noviembre de 1901.

${ }^{77}$ El rompecabezas carlista. (Canal i Morell, 2005, p. 47).

${ }^{78}$ El Pueblo, no 107. Tortosa, 21 de febrero de 1903.

${ }^{79}$ El Radical, no 1835. Almería, 23 de mayo de 1908.
} 


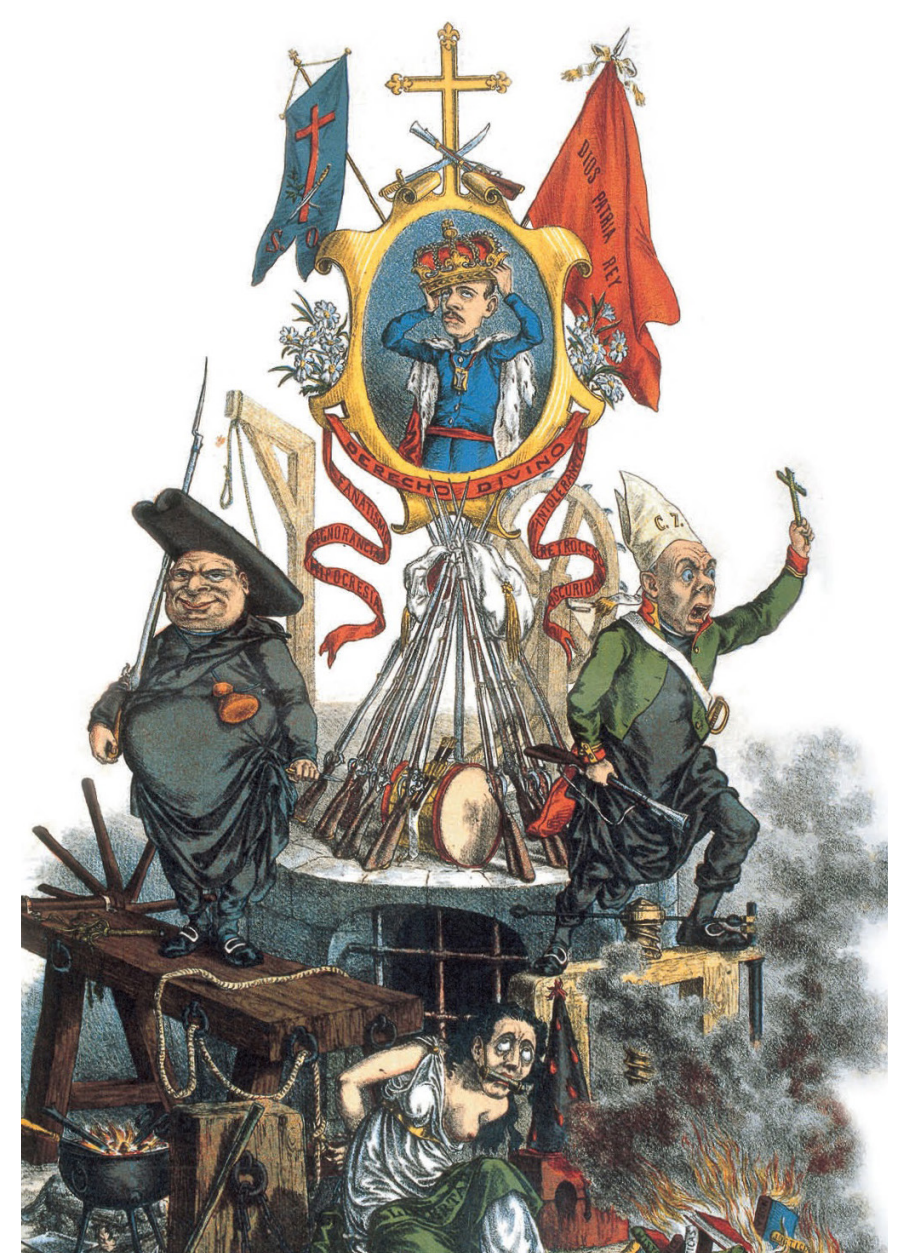

El semanario La Risa denunció con esta caricatura la alianza entre carlistas y los sectores más reaccionarios del clero español (15 de junio de 1872) ${ }^{77}$.

por su crueldad y violencia, siendo responsable de múltiples asesinatos y fusilamientos. Pero de la mucha documentación consultada referente al cura de Alcabón, solamente hemos encontrado una noticia, no confirmada, publicada el 8 de agosto de 1869 por el periódico Alianza del Pueblo de Salamanca: "Dice El Imparcial que en La Mancha ha sido asesinado un niño por la partida del cura de Alcabón"80. El propio periódico comunica la in noticia con escasa firmeza, la noticia proviene de otro medio: El Imparcial. agosto de 1869. 
La ponemos en duda. En ninguna otra información periodística (y hemos consultado 454 registros $^{81}$ ), aparece alguna otra noticia relacionada con fusilamientos o asesinatos por parte de la partida del cura de Alcabón. Sus actuaciones estaban dirigidas hacia el robo, saqueo y pillaje de bienes particulares y de la administración local y estatal, además de causar el mayor daño posible a líneas de telégrafos, ferrocarriles, registros civiles y municipales, etc. Esto no quiere decir que sus guerrilleros fueran "ángeles del cielo", sino que cometerían las barbaridades y atropellos propios y característicos de una guerra. La identificación de las conductas de los curas de Santa Cruz y de Alcabón no es justa, ni coincide con la realidad.

El carácter de don Lucio Dueñas nos lo refleja muy bien Benito Pérez Galdós (2005, pp. 5453-5456), en su obra Episodios Nacionales, en el título "España sin Rey", publicado en 1907. Habla de él en estos términos:

El cura de Alcabón, don Lucio Dueñas, [...] tan fanático y cerril que perdía el sentido en cuanto el viento a sus orejas llevaba rumores de guerra carlista, [...] convocaba inmediatamente al vecindario del mísero pueblo de Alcabón y reclutaba una docena o algo más de gandules dispuestos a defender con su sangre y con su vida la unidad católica y la monarquía absoluta, [...] echaba la llave a la iglesia, cogía la escopeta, enjaezaba su rocín flaco, y ¡hala! a pelear por Dios y por Carlos VII.

\section{CONCLUSIONES}

El presente artículo contribuye a completar los conocimientos que sobre las guerras carlistas tenemos en la provincia, y por tanto en la región. Nada se había publicado hasta ahora sobre los sucesos que ocurrieron el 27 de diciembre de 1874 en la aldea de Pradorredondo, en el término municipal de Lezuza. Son de suma importancia, tanto por la magnitud de la operación (120 carlistas muertos), como por los personajes que los protagonizaron, uno de ellos, don Lucio Dueñas, el célebre cura de Alcabón.

Hasta ahora, lo que sabíamos sobre el cura de Alcabón lo podíamos conseguir de lo publicado por A. Pirala en su obra Segunda parte de

\footnotetext{
${ }^{81}$ La mayoría de los registros han sido consultados en línea en la siguiente dirección: https://prensahistorica.mcu.es/es/consulta/resultados_ocr.do
} 
la guerra civil. Anales desde 1843 hasta el fallecimiento de don Alfonso $X I I$, al que le dedica un capítulo en el volumen II. De esta fuente obtiene su información la enciclopedia Espasa, en la edición de 1920. Las dos obras, sobre todo la primera, nos ofrecen algunos datos sobre las correrías del cura guerrillero, a veces con algunas imprecisiones. Terminan ambas publicaciones cuando don Lucio regresa de su segundo destierro en Cuba y es canjeado por prisioneros liberales en mayo de 1874. A partir de esta fecha, nada más conocíamos. La obra El carlismo en Castilla La Mancha (1833-1875), de M. Asensio, nos aporta muchísimos datos sobre las guerras carlistas en la región, sí que hace mención a don Lucio Dueñas, como jefe de algunas partidas en Toledo y Ciudad Real, pero tampoco detalla nada sobre lo que ocurrió en Pradorredondo en diciembre de 1874.

Investigando estos hechos de Pradorredondo, aprovechamos y hacemos un estudio sobre la Primera Guerra Carlista y sus efectos en Lezuza y su comarca. Un dato a destacar es que las partidas carlistas en esta primera guerra son mucho más numerosas que en la tercera. Así, encontramos que las tropas de Ramón Cabrera cuando se mueven por Balazote suman 800 hombres armados; o el ejército que acompaña al coronel Tallada cuando cruza por Barrax y Lezuza con dirección a Andalucía, lleva más de 2.300 soldados. Vicente Rugero, apodado Palillos, cruzó la vega de Lezuza con 150 jinetes, y su facción llegó a alcanzar los 500 guerrilleros.

Por otro lado, en la primera guerra hay mucha más violencia y derramamiento de sangre que en la tercera. Descubrimos en la comarca numerosos fusilamientos de un bando y de otro: en El Bonillo, Ossa de Montiel, Munera, y también en la villa de Lezuza, donde tropas carlistas fusilarían a ocho individuos del "cuerpo de movilizados" en 1838, y dos años más tarde, a cuatro carabineros.

Lezuza y los pueblos de alrededor sufrían con mucha frecuencia el paso de tropas carlistas, debido a su situación geográfica, que comunicaba el centro peninsular con el levante; y el Maestrazgo con Andalucía. Las partidas perpetraban robos a los particulares y a los recaudadores de contribuciones, causaban crímenes, incendios, saqueos, secuestros a cambio de exigir rescates, etc., lo que obligaba a las autoridades locales a tomar medidas de protección. En Lezuza, en 1837 se determina "cerrar y cercar este pueblo por las partes que mejor sea" para evitar la entrada de "facciosos". También toman acuerdos para que 
si se aproximan los carlistas, las fuerzas nacionales y "demás pudientes" se refugien en el castillo de Peñas de San Pedro. Lo mismo harán otras poblaciones, como Albacete capital.

La segunda guerra (1846-1849), apenas tiene incidencia en la provincia, y no se tiene constancia de que se viera afectada Lezuza y su comarca.

La tercera guerra va a tener una fuerte repercusión en toda la provincia de Albacete, sobre todo durante los años 1873 y 1874. Como hemos señalado anteriormente, las partidas son menos numerosas, siendo lo normal que llevasen entre 40 y 50 guerrilleros. Continúan los robos, el pillaje de trigo y cebada, incendios de archivos en los ayuntamientos y juzgados, daños a líneas de telégragos y vías de ferrocarril. Los fusilamientos, tan comunes en la primera, ahora son excepcionales, pero algunos se produjeron, como es el caso del coronel carlista Miguel Lozano Herrero, que fue ejecutado el 3 de diciembre de 1874, en la vereda de Acequión en Albacete.

Pocos días después de la ejecución de Lozano, el 25 de diciembre de 1874, se va a divisar una partida de carlistas entre La Roda y Minaya. El teniente coronel Portillo salió tras ella y le dio alcance el día 27 en la aldea de Pradorredondo (Lezuza). Se produjo un enfrentamiento armado en el que perdieron la vida 120 carlistas. Según Portillo, la batalla se produjo en campo abierto. Según un periódico de signo carlista, El Iris, los carlistas fueron hechos prisioneros y después asesinados. Por los documentos que se conservan en el Juzgado de Paz de Lezuza, deducimos que los aldeanos de Pradorredondo entablaron contacto con los carlistas, llegando a conocer de algunos de ellos sus nombres, su procedencia y hasta el número de hijos que tenían. Lo que cuentan los vecinos de Pradorredondo, y así se lo transmitieron sus antepasasados, es que muchos carlistas fueron ejecutados dentro de las casas, en el horno y en la placeta de la aldea.

En el informe que el teniente coronel Portillo eleva al gobernador militar de Albacete (ver doc. no 4) las tropas gubernamentales estaban formadas por dos compañías de infantería y 100 jinetes de caballería (suponemos que un mínimo de 200 hombres armados). El número de soldados del ejército carlista ascendía, según Portillo, a 240 soldados, entre infantería y caballería (probablemente este número fuese magnificado para dar más heroicidad a la acción bélica). La cifra de 120 muertos carlistas, próxima al 50\% del total de la partida, es imposible 
que corresponda a una batalla en campo abierto, pues en estas nunca moría un porcentaje tan alto de combatientes, y menos, que todos los muertos cayeron de un único bando, resultando el otro bando salir victorioso sin contar ninguna baja, tan solo 16 heridos. Por tanto, podemos concluir que la partida que mandaba don Lucio Dueñas, el cura de Alcabón, fue masacrada en Pradorredondo por la columna del teniente coronel Portillo.

El cura de Alcabón fue un personaje famoso y "mediático" en la filas del carlismo. Hemos indagado sobre él en diversas fuentes (Pirala, Espasa, Asensio), pero fundamentalmente hemos hecho un seguimiento del mismo a través de los documentos encontrados en periódicos, revistas, boletines oficiales, ... de la época, y hemos podido reconstruir su biografía.

Don Lucio Dueñas ya participó en la primera guerra cuando era seminarista en Toledo, llevando municiones a los carlistas. Se distinguió por su participación en "La Ortegada" en 1860. Después organizó y dirigió diversas partidas carlistas que actuaban sobre todo en las provincias de Toledo y Ciudad Real, aunque llegaban también a Madrid y a Extremadura. Se dedicaban al robo y a la extorsión. Fue perseguido por el ejército y la Guardia Civil, escapándose en numerosas ocasiones. También fue detenido, juzgado, encarcelado, amnistiado, indultado, sufriendo destierro dos veces, una en Francia y la otra en Cuba.

Tras la finalización de la tercera guerra, va a ser indultado nuevamente, y siguió ejerciendo su labor de sacerdote. La prensa no se olvidó de él, al igual que de otros curas que destacaron como guerrilleros carlistas. Van a ser noticia de forma recurrente junto al cura de Alcabón, el cura Santa Cruz, el cura de Flix, mosén Pacho y el Obispo Caixal, entre otros. A través de la prensa histórica hemos rastreado la última fase de su vida, en la que se enfrentó a don Cándido Nocedal, jefe del partido Carlista. Don Cándido era partidario de la actuación del carlismo dentro de la legalidad, lideraba la corriente de los llamados "neocatólicos". Don Lucio, junto a otros carlistas históricos, abogaba de nuevo por una sublevación militar.

Debemos resaltar la importancia de la documentación hallada en la prensa histórica, que nos ha permitido seguir las andanzas y desventuras de don Lucio Dueñas desde 1869 hasta su muerte en 1901. Pero no termina aquí su repercusión en los periódicos. Hemos encontrado abundantes artículos en los que se le cita, hasta el año 1935. 
La prensa consultada ha sido principalmente la de Madrid, aunque la figura del cura de Alcabón saltaba todos los límites territoriales y llegaba a todas las provincias españolas, e incluso hasta la isla de Cuba. Hay que reseñar que la prensa de Albacete no hemos podido consultarla. Cuando se producen los sucesos en Pradorredondo, año 1874, se publicaba el Boletín Oficial de la Provincia, pero desgraciadamente los números publicados en las fechas en que ocurrieron los hechos no se conservan en el Archivo Histórico Provincial. De conservarse, es probable que hubiésemos encontrado información sobre los sucesos de Pradorredondo.

Por último, debemos remarcar que los guerrilleros carlistas fueron fuente de inspiración para numerosos escritores españoles. Entre ellos, destacamos a Benito Pérez Galdós, Valle Inclán, Miguel de Unamuno y Pío Baroja. Este último recuerda en su novela La nave de los locos la figura de Vicente Rugero, alias Palillos, guerrillero natural de Almagro, con fama de sanguinario, que cruzó por la vega de Lezuza en 1840 con 150 jinetes. Pérez Galdós, en un capítulo de los Episodios Nacionales, hace un retrato del apasionado y tozudo cura de Alcabón, del que dice que era "un buen hombre en el fondo". 


\section{REFERENCIAS BIBLIOGRÁFICAS}

ARNABAT, R. (2018). Cuadernos de civilización española contemporánea. Obtenido de https://journals.openedition.org/ccec/7678

ARÓSTEGUI, Julio; CANAL, Jordi; GONZÁLEZ CALLEJA, Eduardo. (2003). El carlismo y las guerras carlistas. Hechos, hombres e ideas. Madrid: Anzos. La Esfera de los Libros, S.L.

ASENSIO RUBIO, M. (2011). El carlismo en Castilla La Mancha (18331875). Ciudad Real: Almud Ediciones. Biblioteca Añil.

BAROJA Y NESSI, P. (1980). La nave de los locos. Madrid: Caro Reggio.

CANAL i MORELL, J. (2005). Carlismo y contrarrevolución. En La Aventura de la Historia, no 77, 45-51.

CARIDAD SALVADOR, A. (2014). Cabrera y compañía. Los jefes del carlismo en el frente del Maestrazgo (1833-1840). Zaragoza: Institución Fernando el Católico. Excma. Diputación de Zaragoza.

CÓRCOLES JIMÉNEZ, M. P. (1999). Algunas noticias sobre carlistas en Albacete (Años 1835-1840). Albasit, no 42, 158-186.

CRUZ HERRERA, M. P. (1993). Diccionario de gentilicios y seudogentilicios de la provincia de Albacete. Zahora, no 42, 1-170.

ESPASA. (1920). Enciclopedia Universal Espasa. En Espasa, Enciclopedia Universal Espasa (págs. 2382, tomo 18). Madrid: Espasa.

HERRERO BERNABÉ, I. (2012). El derecho de gracia: indultos. Tesis Doctoral. Madrid: Universidad Nacional de Educación a Distancia.. LÓPEZ-TORRES RUIZ, B. (1992). Historia de la villa de Lezuza. Albacete: Ayuntamiento de Lezuza.

MARTÍNEZ LACABE, E. (2002). Aproximación prosopográfica a los soldados carlistas en la guerra 1872-1876. Huarte de San Juan, no 9. Universidad Pública de Navarra, 121-198.

PANADERO MOYA, C. (2002). El siglo XIX en la historia de Albacete: balance historiográfico. En PANADERO MOYA, C; REQUENA GALLEGO, M. (Coords.) (2002). II Congreso Historia de la provincia de Albacete. (IV). Edad Contemporánea (págs. 11-18). Albacete: Instituto de Estudios Albacetenses.

PÉREZ DE RADA Y CAVANILLES, Í. (2011). La partida de Palillos y su estandarte, 1833-1840. Revista de la Historia Contemporánea, 4-19. PÉREZ GALDÓS, B. (2005). Episodios Nacionales. España sin rey. Capítulo XX. Madrid: Club Internacional del Libro. 
PIRALA, A. (1892). Segunda parte de la guerra civil. Anales desde 1843 hasta el fallecimiento de don Alfonso XII. Volumen II. Madrid: Felipe González Rojas.

PIRALA, A. (1892). Segunda parte de la Guerra Civil. Anales desde 1843 hasta el fallecimiento de don Alfonso XII. Volumen V. Madrid: Felipe González Rojas.

ROA EROSTARBE, J. (1891-94). Crónica de la provincia de Albacete. Albacete: Viuda de J. Collado.

SÁNCHEZ ORTEGA, D. (2013). Barrax en el siglo XIX. En Cuadernos de Barrax, nํ․ Albacete: Asociación Cultural La Coscoja. Barrax.

SÁNCHEZ TORRES, F. J. (1916). Apuntes para la historia de Albacete. Albacete: Eliseo Ruiz.

TUSELL GÓMEZ, J. (1996). Historia de España Contemporánea. Madrid: Santillana.

VALERO DE LA ROSA, E. (2015). Fortificaciones militares en Albacete durante las guerras carlistas. Albasit, no 60, 279-302.

VALERO DE LA ROSA, E. (1993). Tesoros que traspasan fronteras. Torre de Juan Abad y la gallina de los polluelos de oro. Zahora, no 58, 35-36. 


\section{APÉNDICE DOCUMENTAL}

\section{Documento no 1}

\section{Fusilamientos realizados por una facción carlista en Lezuza, el día 31 de mayo de 1838.}

Fueron asesinados siete individuos pertenecientes al "cuerpo de movilizados". Aquí se transcribe el registro de uno de ellos, (cadáver no 1 ).

AHDAB. Parroquia de Lezuza. Defunciones, libro no 7. LEZ 038, folio 94.

Como cura propio de la iglesia parroquial de Ntra. Sra. de la Asunción de esta villa de Lezuza, provincia de Albacete, mandé dar sepultura eclesiástica al cadáver de Gerónimo Asenjo, natural de Plasencia, provincia de la misma, de estado casado, perteneciente al cuerpo de movilizados de esta provincia, que fue fusilado por la facción que invadió esta población en el día de la fecha, se ignora la edad que tenía y no testó ni hizo ninguna otra disposición. Y para que conste, lo firmo en treinta y uno de mayo de mil ochocientos treinta y ocho. Fdo: Don Martín Trinidad Cantos.

\section{Documento no 2}

\section{Fusilamientos realizados por la facción de La Mancha en Lezu- za, el día 27 de mayo de 1840.}

Fueron asesinados cuatro individuos pertenecientes al cuerpo de "carabineros de la Hacienda Nacional". Aquí se transcribe el registro de uno de ellos (cadáver no ${ }^{4}$ ).

AHDAB. Parroquia de Lezuza. Defunciones, libro no 7. LEZ 038, folio 123.

Diego Cebrián, soltero, hijo de Alonso Cebrián. Como cura propio que soy de la Igleisa Parroquial de Ntra. Sra. de la Asunción de esta villa de Lezuza, provincia de Albacete, mandé dar sepultura eclesiástica en el día de la fecha al cadáver de Diego Cebrián, de estado soltero, hijo legítimo de Alonso Cebrián, naturales y vecinos de Albacete, edad como unos treinta años, el cual fue sorprendido en la villa de Balazote el día veintiséis del corriente mes por la facción de La Mancha, últimamente sublevada en Fernán Caballero, y al día siguiente fue bastardamente asesinado por dicha facción 
en el término y jurisdicción de esta villa de Lezuza, sin haber recibido sacramento alguno, ni haber hecho, que se sepa, declaración alguna testamentaria. Fueron testigos de su enterramiento José Martínez Giménez, Antonio Tendero y Acacio González, de esta vecindad. Y para que conste lo firmo a veinte y ocho de mayo de mil ochocientos cuarenta. Fdo: Martín Trinidad Cantos.

\section{Documento no 3}

\section{Documentos encontrados en el Juzgado de Paz de Lezuza, don- de se relacionan ocho cadáveres de soldados carlistas muertos el 27 de diciembre de 1874, pertenecientes a la facción que acaudillaba el cura de Alcabón.}

Archivo Histórico del Juzgado de Paz de Lezuza. Registro Civil. Libro de defunciones. Tomo 3, folio 67. (Ocho papeles sueltos, tamaño cuartilla, junto a la inscripción no 124).

№ 1ํ. Cadáver= Romualdo García Monsalvo, de Tarancón, casado con María Salboy Bueno, aquél como de unos 43 años; dijo tener un hijo llamado Gregorio García; y aquél era hijo de Mamuel García y de Segunda Monsalvo. Lezuza, 27 de diciembre de 1874.

Acción de Pradorredondo; columna del Teniente Coronel Portillo; facción la que acaudillaba el conocido por el cura de Alcabón, D. Lucio Dueñas. Murieron 67 carlistas.

№ 2․ Cadáver. Un sacerdote, como de 36 a 40 años, grueso, color blanco, el cual se hallaba desnudo, excepto de la camisa que era de hilo, abultado de cara, con entradas en la cabellera y nariz abultada, se halló cadáver en la senda de Fuentepinilla; el cual según todos los antecedentes era natural de Villagarcía, partido de la Motilla del Palancar, provincia de Cuenca. 27 de diciembre de 1874.

Número 3ํ. Cadáver= Un joven como de 18 a 20 años, pelo negro, color al parecer bueno, decentemente limpio, peinado hacia atrás, estatura regular, fue sepultado en el pozo de los 52 . Falleció en la acción de Pradorredondo dada por el Teniente Coronel Portillo contra la facción que acaudillaba don Lucio Dueñas, conocido por el cura de Alcabón, el día 27 de diciembre de 1874; a cuya partida corresponde este cadáver= Lezuza 27 de diciembre de 1874. 
Número 4o․ Cadáver $=$ Un hombre junto a la rambla de Pradorredondo, como de 50 a 51 años, pelo canoso, aumentando éstas por detrás de ambas orejas, barba entrecana, color al parecer bueno, estatura regular; y según manifestación de un aldeano de esta, aquél era natural de Alcázar de San Juan y de estado casado.

№ 5․ Cadáver= Alejandro Ocón, de Alcázar de San Juan, casado con Ángela Alaminos, aquél de unos treinta años, dijo tener hijos. Murió en la acción de Pradorredondo por la columna del Teniente Coronel Portillo y pertenecía a la facción que acaudillaba el conocido por el cura de Alcabón, llamado D. Lucio Dueñas. Lezuza 27 de diciembre de 1874 .

№ 6으. Cadáver= Demetrio Giménez, natural de Yepes, hijo de Juan y Dorotea Cuervo. Antecedentes que antes de morir facilitó a los aldeanos de Pradorredondo. Murió en la acción que en esta aldea dio la columna mandada por el coronel Portillo; y el difunto correspondía a la facción que acaudillaba D. Lucio Dueñas cura de Alcabón. Fue sepultado en la fosa que contiene cincuenta y siete de dicha facción el día veintisiete de diciembre de mil ochocientos setenta y cuatro.

№ 7o. Cadáver= Antonio Domingo Antero Guarasa y Ramírez, hijo de Manuel Ablona, natural de Fuencaliente, de veintisiete años de edad, casado con Pascasia Cecilia Molina y Adán, natural y residente en la villa de Mestanza, provincia de Ciudad Real; tiene dos hijos (Constanza) digo Crisanta y Agustín. Sepultado en la fosa consecutiva de once de los carlistas fallecidos en la acción de Pradorredondo; que se dio por el Teniente Coronel Portillo contra D. Lucio Dueñas= Pradorredondo 27 de diciembre de 1874.

№ 8. Acción de Pradorredondo dada por el Teniente Coronel Portillo, contra la facción que acaudillaba D. Lucio Dueñas, cura de Alcabón. 27 de diciembre de 1874.

Se tomaron antecedentes del cadáver llamado = Romualdo Clemente Aparicio, por ellos resultó ser natural de Toledo, como de cuarenta y dos años, barba negra, pelo ídem, estatura de unos cinco pies, con una cicatriz grande en la frente.

El secretario del Juzgado de Paz de Lezuza, el que escribe los documentos, es D. José María González. El Juez municipal se llamaba D. Juan García Mendieta. 


\section{Documento no 4}

\section{Narración militar del teniente coronel Portillo de la acción de Pradorredondo (Lezuza) contra la facción que acaudillaba don Lucio Dueñas, el cura de Alcabón. 27 de diciembre de 1874.}

Narración militar de la guerra carlista (1869-1876), por el Cuerpo Mayor del Ejército, publicada por el Depósito de la Guerra. Tomo XIII. Madrid. Imprenta y Litografía del Depósito de la Guerra. 1889. Págs. 223-228.

En línea. Consulta: 08/12/2017. Disponible en: http://archive. org/stream/narracinmilitar07guergoog/narracinmilitar07guergoog_ djvu.txt

Noticioso el Gobernador militar de Albacete de que la partida levantada en Castilla la Nueva por el cura de Alcabón había atravesado la vía férrea, entre Minaya y La Roda, para encaminarse a los montes de Toledo, envió el 25 de Diciembre tras él a Portillo con su columna. Con fecha 3 de Enero este jefe relató así desde Cieza las operaciones que dieron por resultado la disolución de dicha partida.

«A las ocho de la mañana del 25 del mes próximo pasado, y por disposición del Sr. Gobernador militar, salí de Albacete hacia La Roda, con la columna a mis órdenes, para perseguir a la partida mandada por el cura de Alcabón, que se dirigía al parecer a Quintanar del Rey. Al buen éxito de mis operaciones convenía hacer la marcha por la vía férrea, pero la falta de material me obligó a andar las cinco leguas de carretera que separan este pueblo de la capital de la provincia, terminando la jornada a las cuatro de la tarde.

Ninguna noticia pude adquirir de la acción, por lo cual alojé la fuerza y tomé las medidas que creí oportunas, a fin de averiguar el paradero de los carlistas. A las ocho de la noche supe por un confidente que se encontraban en las Casas de Guijarro, provincia de Cuenca, distantes de La Roda unas tres leguas; y a las nueve partí en aquella dirección, después de haber telegrafiado al Comandante militar de Alcázar de San Juan manifestándole el punto en que se hallaba la partida e indicándole que, en mi concepto, ésta se proponía cruzar la vía férrea por las inmediaciones de Minaya, por donde creía conveniente le cerrase el paso.

Después de tres horas de marcha, uno de los propios que en 
diferentes direcciones había yo mandado, me participó que los facciosos habían salido a las seis de la tarde de las Casas mencionadas y tomado la ruta que indiqué al Comandante de Alcázar de San Juan. Comprendiendo que era imposible darles alcance siguiéndoles la pista, pues la distancia que de ellos me separaba no era fácil de salvar, retrocedí a La Roda, adonde llegué a las siete de la mañana del día 26. Allí vi confirmada la noticia de que la facción había cruzado la vía por cerca de Minaya, y supe que se dirigía a las Casas de Santa Marta, distante tres leguas de aquella población.

Necesitaba dar algún descanso a mi columna, que hacía la marcha con un fuerte temporal de viento y hielos, y ganar el tiempo que perdiese aprovechando el ferrocarril. Pedí un tren a Albacete, y a las once salí con la infantería y 30 caballos (únicos que pude embarcar), ordenando que los 70 restantes, al mando del capitán del regimiento caballería de España D. Gregorio Maitiif, marchasen al trote por la carretera a incorporárseme.

En las Casas de Santa Marta me enteré de que la partida había dormido en ellas, abandonándolas a las siete de la mañana para ir a las Casas de Montoya; y con objeto de no perder la pista, me adelanté con la caballería, en cuanto la tuve reunida, ordenando a la infantería que continuara tras mí con la mayor celeridad posible.

A las diez de la noche llegué a las Casas últimamente citadas, donde adquirí el conocimiento de que el enemigo después de haber descansado allí algunas horas, había seguido a las Ventas de Tiriez. La infantería se me incorporó a las doce, y a las dos de la madrugada del 27 emprendí de nuevo la marcha con toda la fuer$\mathrm{za}$, resuelto a no dejar descansar a los carlistas hasta obligarles a dispersarse o hacerme frente.

Sabedor en las Casas de los Pardales de que la facción estaba a media legua, en las Ventas antes mencionadas, distribuí mi fuerza del modo siguiente: una compañía de las dos de infantería, con su capitán Sr. Llamas, marchó por el camino de las casas de Berruga a situarse al E. del adversario, para atacarle si intentaba la retirada por aquel punto, o permanecer en caso contrario a la vista hasta recibir mis órdenes; la otra compañía, al mando de su capitán Sr. Cinnati, fue por el camino de La Junquera a colocarse al O. de las referidas Ventas, con iguales instrucciones, pero dejando una sección sobre el camino que conduce a las mismas por la parte $\mathrm{N}$.; y calculando que el enemigo, caso de no resistir, había de emprender la retirada por el S. y en dirección a un espeso bosque, distante me- 
dia legua de sus posiciones, me adelanté con la caballería al trote largo, ocultando mi marcha, con objeto de cerrarle el paso.

De este modo, Excmo. Señor, ocupaba con mi reducida columna los cuatro puntos por donde la disposición del terreno permitía atacar a los facciosos, con la esperanza de que las fatigosas jornadas que llevaba hechas diesen el resultado que me proponía. En mi avance, divisé al adversario que marchaba hacia donde yo sospechaba. Al verme se dividió en tres grupos, situándose uno, compuesto sólo de la caballería, en el cerro de la choza de Rebullo; al pie de éste, la mitad de su infantería; y el resto, en otro cerro que se encuentra entre Pradorredondo y Tiriez.

Inmediatamente ordené que el teniente del regimiento caballería de España Sr. Centeno, avanzase con 20 tiradores hacia la infantería situada al pie del cerro, y que otra sección del mismo cuerpo, a las órdenes del valiente y decidido sargento Agustín Sánchez, lo efectuase por la izquierda, con objeto de proteger a aquel oficial, si era necesario, o de cargar al enemigo, si por este lado quería retirarse. Los facciosos intentaron envolver con su caballería la sección del sargento Sánchez; pero a la par que advertí a éste del peligro, ordené que cargase sobre aquélla el alférez de dicho regimiento de España D. Inocencio de la Buena, e inmediatamente ejecuté yo lo mismo sobre la infantería carlista con el resto de mi caballería, siendo dispersado el contrario con grandes pérdidas, que hubieran sido mayores si la nieve que comenzó a caer al principio de la acción y la espesa niebla con que se obscureció el horizonte, no hubiesen protegido a los que, declarados en vergonzosa fuga, pudieron salvarse del ardor con que los perseguían mis valientes soldados, huyendo por diferentes puntos. La caballería que tomó el camino de Ballestero fue perseguida hasta más de legua y media por el teniente Centeno, el cual le mató siete hombres y siete caballos y le cogió ocho de éstos, cinco de les cuales fueron devueltos a los vecinos de aquellas cercanías a quienes habían sido robados quedando tres en poder de la columna.

La fuerza que mandaba el cura de Alcabón se componía de 200 infantes y 40 caballos. Sus pérdidas han consistido en 114 muertos, entre ellos un teniente coronel y muchos oficiales, y todos han sido recogidos de orden mía por las comisiones de las poblaciones inmediatas, que acudieron a felicitarme sobre el campo de la acción, en cuatro prisioneros; tres caballos muertos, además, de los siete antes mencionados; dos cargas de armas, un botiquín, 
muchas municiones, y raciones de pan y pienso. Las de mi columna consisten en 16 heridos, 20 contusos y un caballo muerto.

Este hecho de armas, cuyo resultado numérico de bajas equivale a la disolución de la partida, pues han debido ocurrir muchas no vistas a causa de lo quebrado del terreno, lo dilatado del campo de la acción y la copiosa nieve que caía, es además importante porque de la documentación recogida y de la declaración de los prisioneros, aparece ser dicha fuerza el cuadro de un batallón titulado de La Mancha y de un escuadrón llamado del Rey; y así se infiere de las insignias de los que quedaron en el campo, que en su inmensa mayoría eran de oficiales y de clases.

Si he sido prolijo al relatar los detalles que precedieron a esta acción, ha sido para que por ellos comprenda V. E. cuan merecedoras de mención se han hecho todas las tropas a mis órdenes, por las penosas marchas verificadas en días de un incesante temporal de fríos vientos, hielos y nieve; por la falta de descanso y la imposibilidad de racionarse; por su envidiable disciplina, y por su ardor difícil de pintar.

Y si a los mencionados en este parte he de añadir los que individualmente se distinguieron, porque así se lo proporcionó la fortuna, diré a V. E. que el soldado de caballería Santiago Ramón Gambán se defendió solo de siete enemigos dejando a tres muertos sobre el campo y haciendo huir a los cuatro restantes, y que otros muchos tuvieron también ocasión de distinguirse. Igualmente debo mencionar a V. E. el paisano José García Caballero, que ya me acompañó como práctico en la acción de Cieza contra Lozano, y que en esta se ha encontrado siempre en el sitio del peligro.

Lo recio del combate duró desde las siete hasta las diez de la mañana, y la nieve estuvo cayendo sin interrupción desde aquella hora hasta las tres de la tarde en que marché a Lezuza, dejando a los referidos comisionados el encargo de dar sepultura a los muertos, que era difícil reunir en un solo punto, por ocupar una gran extensión de terreno, y a la hora de mi partida haber ya varios cubiertos por la nieve, siendo esto causa de que no se pudiesen recoger sus armas, lo cual encomendé también a las expresadas comisiones.

Concluyo, excelentísimo Sr. cumpliendo con el estricto deber de recomendar a V. E. a los que componían mi columna; pues todos se excedieron a sí mismos por sus sufrimientos anteriores, y por su valor indomable al frente del enemigo». 